\title{
Digestive Well-Differentiated Grade 3 Neuroendocrine Tumors: Current Management and Future Directions
}

\author{
Anna Pellat ${ }^{1, *}$, Anne Ségolène Cottereau ${ }^{2}$, Lola-Jade Palmieri ${ }^{1}$, Philippe Soyer ${ }^{3}{ }^{\circledR}$, Ugo Marchese ${ }^{4}$, \\ Catherine Brezault ${ }^{1}$ and Romain Coriat ${ }^{1}$ \\ 1 Department of Gastroenterology and Digestive Oncology, Hôpital Cochin, AP-HP, \\ 27 rue du Faubourg Saint Jacques, Université de Paris, 75014 Paris, France; lolajade.palmieri@aphp.fr (L.-J.P.); \\ catherine.brezault@aphp.fr (C.B.); romain.coriat@aphp.fr (R.C.) \\ 2 Department of Nuclear Medicine, Hôpital Cochin, AP-HP, 27 rue du Faubourg Saint Jacques, \\ Université de Paris, 75014 Paris, France; annesegolene.cottereau@aphp.fr \\ 3 Department of Radiology, Hôpital Cochin, AP-HP, 27 rue du Faubourg Saint Jacques, Université de Paris, \\ 75014 Paris, France; philippe.soyer@aphp.fr \\ 4 Department of Surgery, Hôpital Cochin, AP-HP, 27 rue du Faubourg Saint Jacques, Université de Paris, \\ 75014 Paris, France; ugo.marchese@aphp.fr \\ * Correspondence: anna.pellat@aphp.fr
}

check for

updates

Citation: Pellat, A.; Cottereau, A.S.; Palmieri, L.-J.; Soyer, P.; Marchese, U.; Brezault, C.; Coriat, R. Digestive Well-Differentiated Grade 3

Neuroendocrine Tumors: Current Management and Future Directions. Cancers 2021, 13, 2448.

https://doi.org/10.3390/

cancers 13102448

Academic Editor: Alessio Imperiale

Received: 28 April 2021

Accepted: 14 May 2021

Published: 18 May 2021

Publisher's Note: MDPI stays neutral with regard to jurisdictional claims in published maps and institutional affiliations.

Copyright: (c) 2021 by the authors. Licensee MDPI, Basel, Switzerland. This article is an open access article distributed under the terms and conditions of the Creative Commons Attribution (CC BY) license (https:// creativecommons.org/licenses/by/ $4.0 /)$.
Simple Summary: We herein present the latest data on characteristics and therapeutic management of gastro-entero-pancreatic well-differentiated neuroendocrine grade 3 tumors (GEP-NET G-3). Although neuroendocrine neoplasms (NEN) of the digestive tract are rare tumors, progress in diagnosis has allowed their better identification. Since 2017, a new category of NEN showing welldifferentiated morphology and high Ki-67 index has been defined, the NET G-3. These tumors show differences not only in morphology but also in genotype, clinical features, and treatment response, compared with classical high-grade NEN. Therefore, they should be managed differently but suffer from lack of data. We find our work important, underlying the need to conduct new rigorous clinical studies in this population.

Abstract: Digestive well-differentiated grade 3 neuroendocrine tumors (NET G-3) have been clearly defined since the 2017 World Health Organization classification. They are still a rare category lacking specific data and standardized management. Their distinction from other types of neuroendocrine neoplasms (NEN) not only lies in morphology but also in genotype, aggressiveness, functional imaging uptake, and treatment response. Most of the available data comes from pancreatic series, which is the most frequent tumor site for this entity. In the non-metastatic setting, surgical resection is recommended, irrespective of grade and tumor site. For metastatic NET G-3, chemotherapy is the main first-line treatment with temozolomide-based regimen showing more efficacy than platinum-based regimen, especially when Ki-67 index $<55 \%$. Targeted therapies, such as sunitinib and everolimus, have also shown some positive therapeutic efficacy in small samples of patients. Functional imaging plays a key role for detection but also treatment selection. In the second or furtherline setting, peptide receptor radionuclide therapy has shown promising response rates in high-grade NEN. Finally, immunotherapy is currently investigated as a new therapeutic approach with trials still ongoing. More data will come with future work now focusing on this specific subgroup. The aim of this review is to summarize the current data on digestive NET G-3 and explore future directions for their management.

Keywords: neuroendocrine neoplasms; well-differentiated grade-3; functional imaging; chemotherapy

\section{Introduction}

Neuroendocrine neoplasms (NEN) are most often located in the lung and in the digestive tract. They are defined by the expression of specific biomarkers, such as synaptophysin 
and chromogranin A (CGA), which can be absent in high-grade NEN [1-4]. The World Health Organization (WHO) grading system classifies neuroendocrine neoplasms (NEN) according to tumor differentiation and tumor grade (proliferation rate). Well-differentiated grade 3 neuroendocrine tumors (NET G-3) have been introduced in the 2017 WHO classification for pancreatic lesions; this was later generalized to all digestive tumor sites [5]. NET G-3 show well-differentiated morphology and high Ki-67 index (>20\%) [2,6-9]. Both the proliferation rate (Ki-67 index and mitotic index) and differentiation status now separate NEN between well-differentiated NET (NET G-1 to G-3), and poorly differentiated neuroendocrine carcinomas (NEC) of the digestive tract (only G-3) [10] (Table 1).

Table 1. The 2019 World Health Organization (WHO) classification for neuroendocrine neoplasms (NEN) of the digestive tract.

\begin{tabular}{|c|c|c|}
\hline Well-Differentiated NEN $^{1}$ & Ki-67 Index (\%) & Mitotic Index ( $\left.\mathrm{HPF}^{2} / 10 \mathrm{HPF}\right)$ \\
\hline NET $^{3}$ G-1 (low-grade) & $<3$ & $<2 / 10$ \\
\hline NET G-2 (intermediate-grade) & $3-20$ & $2-20 / 10$ \\
\hline NET G-3 (high-grade) & $>20$ & $>20 / 10$ \\
\hline \multicolumn{3}{|l|}{ Poorly differentiated NEN } \\
\hline $\begin{array}{c}\mathrm{NEC}^{4} \mathrm{G}-3 \\
\text { Small-cell type, Large-cell type }\end{array}$ & $>20$ & $>20 / 10$ \\
\hline
\end{tabular}

$\frac{\text { Mixed neuroendocrine-nonneuroendocrine neoplasm (MiNEN) }}{{ }^{1} \text { NEN: neuroendocrine neoplasm; }{ }^{2} \text { HPF: high-power field; }{ }^{3} \text { NET: neuroendocrine tumor; }{ }^{4} \text { NEC: neuroendocrine }}$ carcinoma.

Prior to this, all G-3 neuroendocrine samples, or high-grade NEN, were considered as NEC and uniformly evaluated and treated in studies [11]. Data on NEC is detailed in another paper of this special issue. It is now established that well-differentiated NET G-3 have a better prognosis than NEC because of distinct tumor characteristics [7,12,13]. Additionally, functional imaging has offered a new tailored approach in NEN detection, classification and treatment. With all this in mind, NET G-3 should benefit from a specific therapeutic approach with more trials expected to help define their precise management [14-16].

We present in this work the current data on clinical, radiological and pathological presentation as well as treatment, of digestive NET G-3, with a special focus on gastroentero-pancreatic tumors (GEP-NET G-3).

\section{Epidemiological Features and Tumor Presentation}

\subsection{Tumor Location and Incidence}

Digestive NEN are rare tumors with a rising incidence in the context of diagnostic improvement [12,17]. High-grade NEN represent only a small sample of these tumors [18-20]. Precise data is still scarce for NET G-3 due to their recent identification: most data are retrospective and often come from reassessment and reclassification of NEC samples $[6-8,12,21]$.

Studies show that NET G-3 are more often found in the pancreas with a frequency ranging from $10 \%$ to $65 \%[3,6,21,22]$. Other main tumor sites are the colon/rectum and stomach, with frequencies ranging from $8 \%$ to $24 \%$ and $8 \%$ to $29 \%$, respectively [3,22].

Regarding incidence, a 2015 retrospective study of 204 patients with GEP-NEN G-3 found 37 (18\%) patients with NET G-3 and 167 (79\%) with NEC [12]. Recently, a Korean study found $8(10 \%)$ pancreatic NET G-3 (PanNET G-3) after reclassification of 82 surgically resected PanNEN [21]. One of the rare prospective studies, the PRONET study, included 1340 samples (biopsy, surgical, endoscopic resection and cytological preparations) of NEN and found 778 patients with GEP-NEN, including 104 (13.5\%) NEN G-3. From those, the proportions of NEC, NET G-3 and mixed neuroendocrine-nonneuroendocrine neoplasm (MiNEN) were $69 \%(n=72), 20 \%(n=21)$ and $11 \%(n=11)$ respectively [22,23]. In summary, the incidence of NET G-3 is probably underestimated, but seems to account for $20 \%$ of 
the NEN G-3 population. With their recent identification, future large epidemiological databases will probably help determine their actual incidence.

\subsection{Clinical Presentation and Biomarkers}

Clinical presentation of digestive NEN shows great heterogeneity. Low-grade NETs are rather indolent tumors often associated with hormonal syndromes (i.e., functional tumors) and sometimes with a hereditary background. Most functional NET are found in the midgut, and functional PanNET represent only a minority of all PanNET [24,25]. On the opposite, NEC are aggressive neoplasms, rarely functional, and with unknown risk factors $[3,7,20]$. According to small available series, NET G-3 patients are more likely to have a functional tumor (5-50\%) compared to NEC patients (0-6\%) (Table 2) $[3,6,7,26]$. Various works found no significant differences in age compared with NET G-2 or NEC patients $[4,6,7,21,27]$ with only two studies suggesting that patients with NET G-3 were younger than those with NEC at the time of diagnosis $[3,26]$.

Table 2. Results from main studies evaluating grade 3 neuroendocrine tumors (NET G-3) patients.

\begin{tabular}{|c|c|c|c|c|c|c|c|}
\hline Study & $\begin{array}{c}\text { Velayoudom- } \\
\text { Céphise et al. } \\
{[6]} \\
2013\end{array}$ & $\begin{array}{c}\text { Heetfeld et al. } \\
\text { [3] } \\
2015\end{array}$ & $\begin{array}{c}\text { Basturk et al. } \\
{[7]} \\
2015\end{array}$ & $\begin{array}{c}\text { Scoazec et al. } \\
{[23]} \\
2017\end{array}$ & $\begin{array}{c}\text { Hijioka et al. } \\
{[4]} \\
2017\end{array}$ & ${ }_{2017}^{\text {Raj et al. [26] }}$ & $\begin{array}{c}\text { Kim et al. [21] } \\
2020\end{array}$ \\
\hline Sample size & 12 & 37 & 19 & 21 & 21 & 16 & 8 \\
\hline Age (year) & $\begin{array}{c}56 \\
\text { median }\end{array}$ & $\begin{array}{c}52 \\
\text { median }\end{array}$ & $\begin{array}{c}54 \\
\text { median }\end{array}$ & $\mathrm{NA}^{7}$ & $\begin{array}{c}63 \\
\text { median }\end{array}$ & $\begin{array}{c}47 \\
\text { mean }\end{array}$ & $\begin{array}{c}57 \\
\text { median }\end{array}$ \\
\hline Tumor location & $\begin{array}{c}\text { Pancreas, } \\
\text { non-digestive }\end{array}$ & $\begin{array}{c}\text { Pancreas, } \\
\text { rectum, } \\
\text { stomach, small } \\
\text { bowel }\end{array}$ & Pancreas & $\begin{array}{c}\text { Pancreas, } \\
\text { colon, rectum, } \\
\text { stomach, small } \\
\text { bowel }\end{array}$ & Pancreas & Pancreas & Pancreas \\
\hline $\begin{array}{c}\text { Metastatic } \\
\text { state }(\%)\end{array}$ & 100 & 62 & 67 & NA & 71 & 69 & 100 \\
\hline $\begin{array}{c}\text { Median Ki-67 } \\
(\%)\end{array}$ & 21 & 30 & 40 & 35 & 29 & 47 & 23 \\
\hline $\begin{array}{c}\text { Positive SRI }^{1} \\
\text { uptake } \mathrm{N}^{2} \text { of } \\
\text { patients } \\
\text { Type of } \\
\text { imaging } \\
\% \text { of positivity }\end{array}$ & $\begin{array}{c}7 / 8 \\
\text { Octreoscan }^{\circledR} \\
88\end{array}$ & $\begin{array}{c}21 / 24 \\
\text { Not specified } \\
87.5\end{array}$ & $\begin{array}{l}\text { NA } \\
\text { NA } \\
\text { NA }\end{array}$ & $\begin{array}{l}\text { NA } \\
\text { NA } \\
\text { NA }\end{array}$ & $\begin{array}{l}\text { NA } \\
\text { NA } \\
\text { NA }\end{array}$ & $\begin{array}{c}13 / 15 \\
\text { Octreoscan }^{\circledR} \\
87\end{array}$ & $\begin{array}{l}\text { NA } \\
\text { NA } \\
\text { NA }\end{array}$ \\
\hline $\begin{array}{l}\text { Functional } \\
\text { tumor }\end{array}$ & $3(25 \%)$ & $5(14 \%)$ & $1(5 \%)$ & NA & NA & $8(50 \%)$ & $0(100 \%)$ \\
\hline ORR $^{3}(\%)$ & NA & 2/12 (17) & NA & NA & $0 / 16(0)$ & NA & NA \\
\hline $\begin{array}{l}\text { Median OS } \\
\text { (months) }\end{array}$ & 41 & 99 & 54 & NA & 42 & 52 & 87 \\
\hline $\begin{array}{c}\text { Median PFS } \\
\text { (months) }\end{array}$ & NA & NA & NA & NA & NA & NA & 16 \\
\hline $\operatorname{DCR}^{6}(\%)$ & NA & 3/12 (33) & NA & NA & $6 / 16(37,5)$ & NA & NA \\
\hline
\end{tabular}

${ }^{1}$ SRI: somatostatin receptor imaging; ${ }^{2} \mathrm{~N}$ : number; ${ }^{3}$ ORR: overall response rate; ${ }^{4}$ OS: overall survival; ${ }^{5}$ PFS: progression free survival;

${ }^{6}$ DCR: disease control rate, ${ }^{7}$ NA: not available. Source: adapted and updated from Pellat et al. [15].

Specific biomarkers such as plasma CGA, plasma neuron specific enolase (NSE) and urinary 5-hydroxyindoleacetic acid (5-HIAA) are frequently used in NEN management. Plasma CGA helps monitor evolution and treatment response in well-differentiated NET [28-30] whereas NSE is more frequently assessed in high-grade NEN [31,32]. Urinary 5-HIAA is specific for carcinoid syndrome monitoring in midgut NET [33]. Data on plasma biomarkers are still very scarce for high-grade NEN. One study on 12 pulmonary and digestive NET G-3 found increased levels of plasma CGA and NSE or urinary 5 HIAA in $42 \%, 25 \%$ and $25 \%$ of patients respectively, with no significant differences with NEC patients [6]. Recently, another study found that blood concentration of FAS ligand (FASLG) was lower in 42 PanNEN G-3 compared to controls, and that positive FASLG immunoreactivity in tumor cells correlated with well-differentiated morphology (14/42 evaluable 
samples) [34]; suggesting that FASLG could be a future candidate biomarker. Finally, PanNET G-3 rarely show high levels of carbohydrate antigen (CA) 19-9 compared with pancreatic adenocarcinoma [35]. These preliminary results on biomarker assessments in NET G-3 need confirmation by future studies.

The scarcity of available data makes it hard to draw firm conclusions on NET G-3 clinical presentation. In case of diagnostic difficulty, a functional tumor is more in favor of NET G-3 than NEC, especially if located in the pancreas. There are currently not enough data to recommend the dosage of any plasma biomarker in digestive NET G-3.

\subsection{Prognosis}

The presence of metastasis is a well-known factor of poor prognosis in NEN, as for other neoplasms $[13,36]$. Both cell differentiation and proliferation rate are also major prognostic markers for NEN [2,9,12]. Grading, itself, plays a major role in the prognosis of well-differentiated NET, thus highlighting the importance of separating NET G-3 patients from others [13,37]. Indeed, a recent study in rectal NET, including four patients with NET G-3, showed that grade was significantly associated with distant metastasis [38].

In various works, the overall survival (OS) for NET G-3 patients was longer than for NEC patients: median survival ranged from 41-99 months versus (vs.) 5.3-17 months $[3,6,7,26,39]$. Regarding PanNEN, one study showed that OS for both NET G-2 and NET G-3 patients was similar (67.8 and 54.1 months, respectively; $p=0.02$ ) and significantly higher than for NEC patients (11 months) [7]. Patients with PanNET G-3 also show better OS than those with ductal pancreatic adenocarcinoma [35]. These results indicate that NET G-3's prognosis falls in between that of NET G-2 and NEC, and more data are needed for non-pancreatic lesions.

\section{Imaging}

\subsection{Functional Imaging}

Functional imaging plays an important role in detection, classification as well as treatment of NEN [40]. Indeed, positron emission tomography/computed tomography (PET-CT) imaging can be used for the selection of candidate patients for peptide receptor radionuclide therapy (PRRT) but can also provide evidence of treatment response (see Section 5). ${ }^{18}$ F-Fluorodesoxyglucose $\left({ }^{18} \mathrm{~F}\right.$-FDG) PET-CT is recommended to help in NEC diagnosis and often indicates poor prognosis when positive in well-differentiated NEN [41-43]. Well-differentiated NET overexpress somatostatin receptors (SSTRs) and most of them show positive somatostatin receptor imaging (SRI) uptake (Octreoscan ${ }^{\mathrm{TM}}$ or ${ }^{68} \mathrm{Ga}$-DOTATOC PET-CT). Furthermore, the combined use of SRI and ${ }^{18} \mathrm{~F}$-FDG PET-CT has led to the development of the NETPET grading score, to help classify and select patients for individualized treatment (i.e., patients with SSTR- and ${ }^{18} \mathrm{~F}-\mathrm{FDG}+$ are less likely to respond to PRRT) $[44,45]$. Indeed, results with dual tracers were correlated with cell differentiation and $\mathrm{Ki}-67$ index values [46].

In the small available series, most patients with NET G-3 showed positive SRI uptake (Table 2) [3,6,26]. In Velayoudom-Céphise et al. [6] and Heetfeld et al. [3] studies, patients with NET G-3 showed significantly more positive SRI than those with NEC ( $p=0.03$ and 0.001 respectively). In a recent work, six NET G-3 lesions showed positive ${ }^{68} \mathrm{Ga}$-DOTATOC PET-CT uptake, and a negative correlation was found between Ki-67 index and SUVmax values in the whole NET population evaluated $(\mathrm{r}=-0.3 ; p=0.018)$ [47]. Regarding ${ }^{18} \mathrm{~F}$-FDG PET-CT, data are even more scarce (Table 2). In Velayoudom-Céphise et al. work, 25\% of NET G-3 patients had a positive ${ }^{18}$ F-FDG PET-CT uptake [6]. In Heetfeld et al. work, only 12 patients of the NET G-3 group were evaluated and 9 had a positive ${ }^{18}$ F-FDG PET-CT uptake (75\% of positivity), which was similar with NEC patients [3]. These results indicate that NET G-3 are more likely to have a positive SRI and should benefit from this type of examination, but ${ }^{18}$ F-FDG PET-CT is not helpful for distinguishing between NET G-3 and NEC. Specific data are still lacking regarding the use of dual tracers in NET G-3, but some 
authors recommend that both SRI and ${ }^{18}$ F-FDG PET should indeed be performed given encouraging results with PRRT in this population [48].

We show here the results of dual tracer functional imaging $\left({ }^{68} \mathrm{Ga}\right.$-DOTATOC PET-CT and ${ }^{18}$ F-FDG PET-CT) for one patient with metastatic PanNET G-3 presenting with positive SRI uptake and incomplete ${ }^{18}$ F-FDG PET-CT uptake (Figure 1).
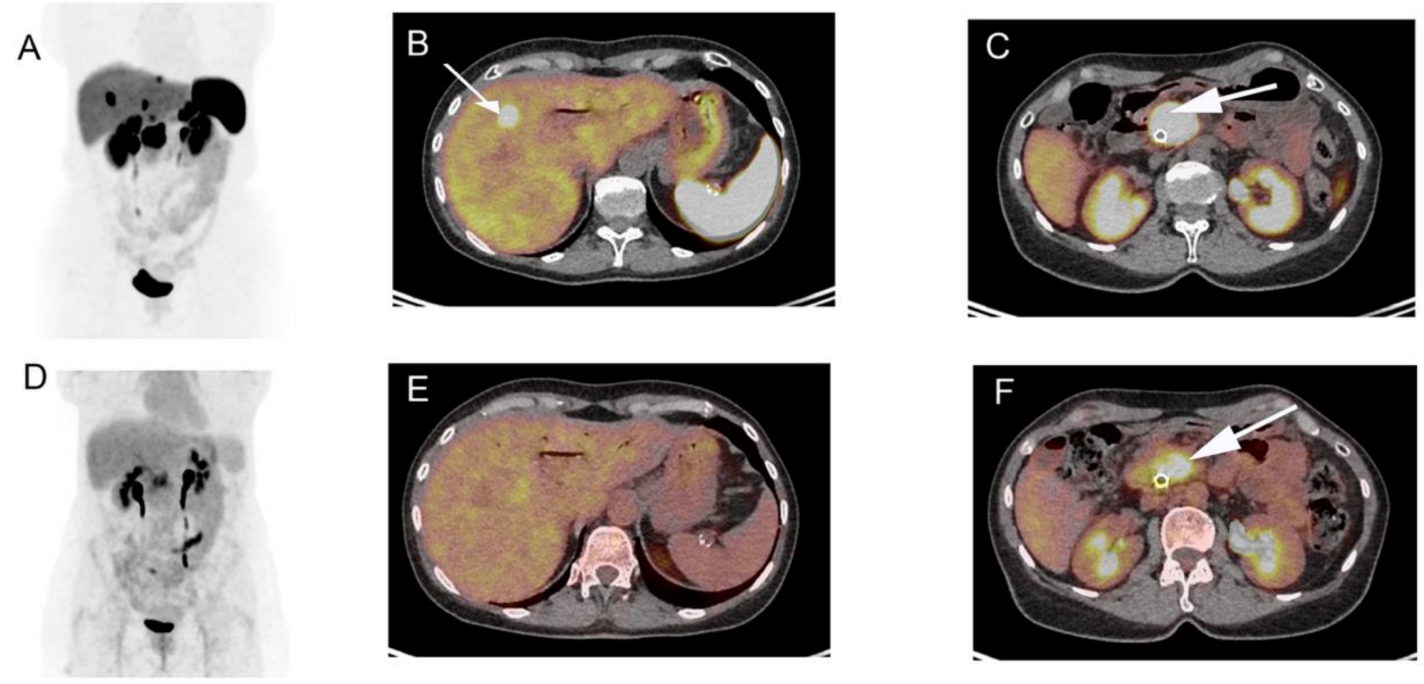

Figure 1. A 45-year-old woman presenting with a large lesion of the pancreatic head, with an initial diagnosis of grade 2 neuroendocrine tumor (NET G-2) after histopathologic analysis of biopsy specimens. Pre-therapeutic ${ }^{68}$ Ga-DOTATOC. positron emission tomography/computed tomography (PET-CT) maximum intensity projection image (A) and axial fused PET-CT images $(\mathbf{B}, \mathbf{C})$ showed multiple liver lesions (B, arrow) and high uptake by pancreatic lesion $(\mathbf{C})$. The ${ }^{18} \mathrm{~F}-\mathrm{FDG}$ PET-CT (D-F) demonstrated high focal uptake only in the central region of the pancreatic tumor (F) and no pathological liver uptake (E), highlighting tumor heterogeneity. Finally, histopathologic analysis of surgical specimens revealed a NET G-3 with Ki-67 index of 22\% and confirmed liver metastasis.

Several preclinical studies have reported on C-X-C motif chemokine receptor 4 (CXCR4)targeted molecular imaging and therapy. CXCR4 is overexpressed in GEP-NET and could act as a potential target for treatment [40]. Pentixafor, an analog of a CXCR4 ligand, has been approved by the Food and Drug Administration in 2008. Werner et al. have studied the feasibility of CXCR4-PET in 12 GEP-NET, including five NET G-3, using ${ }^{68} \mathrm{Ga}$-Pentifaxor in comparison with ${ }^{68} \mathrm{Ga}$-DOTATOC PET-CT and ${ }^{18} \mathrm{~F}-\mathrm{FDG}$ PET-CT: $80 \%$ of NET G-3 exhibited positive CXCR4-PET uptake ( ${ }^{68} \mathrm{Ga}$-Pentifaxor positive lesions) and increasing receptor expression was observed with increasing tumor grade [49]. These results were based on a limited number of patients and need further confirmation, but CXCR4-targeted therapy might possibly play an important role in the future in the field of theranostics for NET G-3.

Regarding other types of functional imaging, there are very little data on PET-magnetic resonance imaging (MRI) in NEN, and none in NET G-3 to our knowledge [50].

\subsection{Morphological Imaging and Radiomics}

Apart from functional imaging, CT and MRI are also frequently used for NEN management in clinical practice, especially for treatment response evaluation. When it comes to tumor diagnosis, researchers have found that several morphologic features such as ill-defined margins, large tumor size, heterogeneous and poor to moderate enhancement, vascular involvement, upstream Wirsung duct dilatation, and distant metastases are less frequently observed in G-1/G-2 NET by comparison with G-3 NEN [51-53]. One recent work looked into the specificities of morphological imaging in 13 patients with NET G-3 compared to 23 with NEC [54]. Patients with poorly differentiated lesions showed larger sized tumors, more necrosis and lower attenuation on pre-contrast and on portal venous phase CT images, with all results being significant [54]. Hemorrhagic content on MRI was 
only present in NEC ( $p=0.007)$ [54]. Due to the rarity of NEC and NET G-3, morphological criteria are mainly used in dedicated multidisciplinary meetings in centers with large output to predict invasiveness.

Radiomics refers to the high-throughput extraction and analysis of quantitative features from medical images [55]. Researchers have also shown that NET G-3 have a suggestive CT radiomics signature that helps differentiate them from NET G-1 and NET G-2 or from NEC $[51,53,54,56]$.

We present here the CT and MRI images of a patient with PanNET G-3 to illustrate the previously described high-grade morphological features (Figure 2).

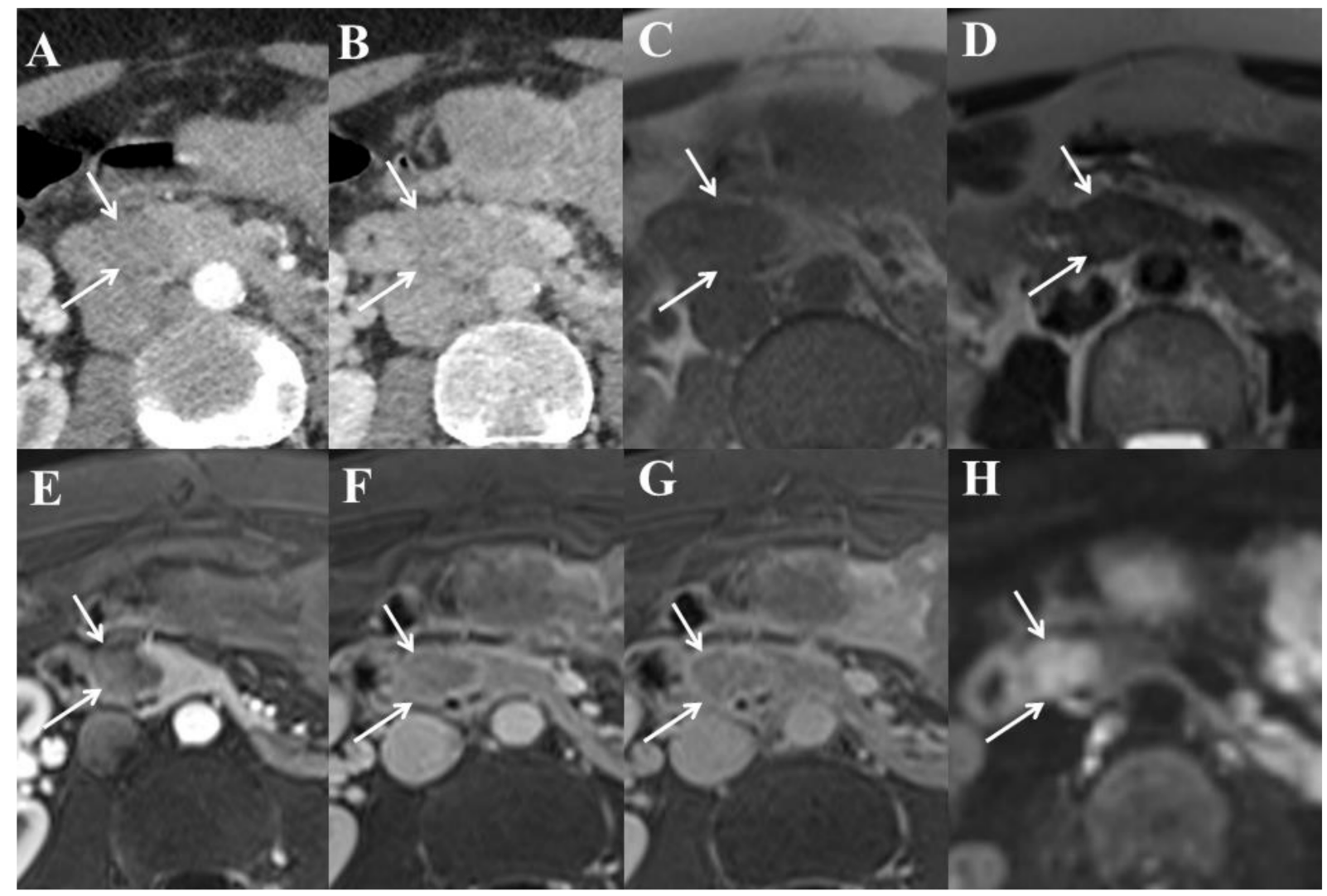

Figure 2. Forty-six-year-old woman with well-differentiated grade 3 neuroendocrine tumor (Ki-67 index $=28 \%$ ) of the pancreatic head (PanNET G-3). (A) Computed tomography (CT) image in the axial plane obtained during the arterial phase following intravenous administration of iodinated contrast material reveals ill-defined, slightly hypoattenuating lesion (arrows) of the pancreatic head. The poor enhancement during arterial phase is in contrast with the classical hyperenhancement observed in well-differentiated PanNET G-1 and G-2. (B) On CT image obtained during the portal phase, the lesion (arrows) is hardly visible. (C) T1-weighted magnetic resonance (MR) image in the axial plane obtained before intravenous administration of a gadolinium-based contrast agent shows hypointense pancreatic lesion (arrows). (D) T2-weighted MR image shows ill-defined and slightly hyperintense pancreatic lesion (arrows). (E) T1-weighted MR image in the axial plane obtained during the arterial phase following intravenous administration of a gadolinium-based contrast agent clearly shows well-defined and markedly hypointense pancreatic lesion (arrows). The poor enhancement during arterial phase is in contrast with the classical hyperenhancement observed in well-differentiated PanNET G-1 and G-2. (F) On T1-weighted MR image obtained during the portal venous phase of enhancement, the lesion (arrows) remains hypointense relative to the adjacent pancreatic parenchyma. (G) On T1-weighted MR image obtained during the late phase of enhancement, the lesion (arrows) remains hypointense relative to the adjacent pancreatic parenchyma. (H) Diffusion-weighted MR image $\left(b=1000 \mathrm{~s} / \mathrm{mm}^{2}\right)$ in the axial plane shows hyperintense pancreatic lesion (arrows). The tumor had a low apparent diffusion coefficient of $0.952 \times 10^{-3} \mathrm{~mm}^{2} / \mathrm{s}$. 
Overall, a functional high-grade NEN with positive SRI uptake is in favor of NET G-3 rather than NEC, especially when located in the pancreas. Morphological imaging can also be used by expert teams to help identify NET G-3 in case of diagnostic difficulty.

Following these first two chapters of our review, we have summarized the results from the largest series studying NET G-3 patients (Table 2).

\section{Histopathology and Molecular Biology}

\subsection{Morphology and Ki-67 Index}

Pathological evaluation is crucial for high-grade NEN classification and often requires an expert NEN pathologist. High-grade NEN show differences in their morphologic features. In PanNET G-3, tumor cells are mostly cuboidal in shape, with abundant cytoplasm and uniform nuclei [21,27]. There is an increased proliferation accompanied with changes in morphology such as apoptosis, mitoses and nuclear tangles [27]. Also, compared with NEC, NET G-3 show less pleomorphism and necrosis [27]. The presence of another histological type can sometimes result in tumor diagnosis difficulty (mixed morphology). The 2017 WHO classification has introduced the notion of MiNEN where any other histological type can be associated with the neuroendocrine morphology (at least 30\% of the tumor sample) (Table 1) [2,9].

Regarding the proliferation rate, $\mathrm{Ki}-67$ index values usually range from 21 to $50 \%$ in NET G-3, whereas NEC often show higher results up to 100\% (Table 2). Although no data on differentiation was available, the NORDIC study on 305 patients with GEP-NEN G-3 showed that patients with Ki-67 index $<55 \%$ had better OS and different treatment response [57]. Following these results, some authors have suggested that the 55\% Ki-67 value could be the best cutoff to distinguish well-differentiated NEN G-3 from NEC [58]. To this day, this has not been validated and clinicians should follow the WHO guidelines for NEN G-3 classification.

An accurate pathological assessment of the Ki-67 proliferation is essential for NEN diagnosis. Technical factors such as the specimen type (biopsy, needle aspiration cytology or surgical specimen), the staining technique, the choice of antibody and the assessment method may potentially affect the reproducibility of Ki-67 index values [59]. Recently, Kalantri et al. found that grading of PanNEN on cytology samples collected by endoscopic ultrasound-guided fine-needle aspiration showed good agreement with results from histology samples [60]. Manual counting (MC) of $>2000$ cells is considered the "gold standard" method by the WHO grading system. MC and digital image analysis (DIA) appear more reliable than "eyeballing" because of marked interobserver and intra-observer variability $[61,62]$. This was particularly observed for the assessment of tumor grades (G-1/G-2 and G-2/G-3 cutoffs) [61]. Nevertheless, in another work Ki-67 index assessment by "eyeballing" was highly correlated with results in DIA [63]. Additionally, compared with DIA, MC and "eyeballing" tended to overestimate the Ki-67 index [61,63]. In practice, $\mathrm{MC}$ remains the gold standard for evaluation of Ki-67 index and can be performed through the microscope or on screenshot printed image, which seems the most practical method based on its cost/benefit ratio and reproducibility [62].

Evolution of a well-differentiated NET to a high-grade NEN has been suggested by some authors. In a single-center retrospective study on 46 patients with 106 lesions of PanNET, increase in tumor grade occurred in 28 patients $(63.6 \%)$ with the majority evolving from G-1/G-2 to G-3 [64]. On top of that, high progression correlated with worst survival [64]. In total, possible grade evolution remains a hypothesis. Other explanations such as sampling error or mixed tumors could also be considered in case of a patient's unexpected clinical presentation. Therefore, multiple biopsies in one patient can sometimes be performed to guide future treatment.

\subsection{Molecular Biology}

Even if pathological diagnosis has improved, in rare cases a grey zone persists for pathologists to distinguish NEC from highly proliferative NET G-3. Morphological charac- 
terization can be difficult in tumors with important tumoral heterogeneity and/or necrosis [27]. Here, molecular biology findings have greatly helped in the distinction between these two entities. NET G-3 seem to have common pathogenetic mechanisms with low and intermediate grades NEN, with key drivers of their molecular pathogenesis differing from those in NEC. As mentioned above, some researchers have suggested that PanNET G-3 might develop from an initial G-1 or G-2, whereas PanNEC could develop from ductal adenocarcinoma $[61,65]$. Small and large-cell NEC of the digestive tract show genetic similarities with frequent inactivation of the TP53, $\mathrm{Rb}$ and SMAD4 pathways, due to intragenic mutations in the TP53, RB1 and SMAD4 genes [66-69]. These genetic changes are rarely seen in well-differentiated PanNEN [66,67]. Conversely, inactivating mutations in DAXX and ATRX and in MEN1 are found exclusively in PanNET [68,70,71]. Mutations in other components of the PI $3 \mathrm{~K} / \mathrm{mTOR}$ signaling pathway including PTEN, DEPDC5, and PIK3CA have also been observed in PanNET [66,70,72]. Finally, a whole-genome sequencing of liver metastasis in a patient with metastatic PanNET G-3 exhibited a TSC1-disrupting fusion, a novel CHD7-BEND2 fusion, but lacked any somatic variants in ATRX, DAXX, and MEN1 [73]. Following these results, in 2016 Tang et al. had proposed a diagnostic algorithm based on frequent molecular alterations to help distinguish between PanNET G-3 and PanNEC [67]. More data is urgently needed in non-pancreatic NET G-3.

We have summarized the main molecular alterations found in high-grade NEN in Table 3.

Table 3. Main molecular alterations found in grade 3 neuroendocrine tumors (NET G-3) versus neuroendocrine carcinoma (NEC).

\begin{tabular}{ccc}
\hline Molecular Alterations (\%) & NET G-3 $^{\mathbf{1}}$ & NEC $^{\mathbf{2}}$ \\
\hline Rb1 mutation & 0 & $67-75$ \\
\hline KRAS mutation & 0 & $28-50$ \\
\hline p53 mutation & 0 & $57-87$ \\
\hline SMAD4 mutation & 0 & 5 \\
\hline Loss of DAXX/ATRX expression & $45-47$ & 0 \\
\hline
\end{tabular}

${ }^{1}$ NET G-3: grade 3 neuroendocrine tumor; ${ }^{2}$ NEC: neuroendocrine carcinoma.

\section{Treatment}

Therapeutic management of digestive NET G-3 is not completely standardized because of their rarity and the lack of well conducted robust trials. Here, we address the different therapeutic options with available data in NET G-3.

\subsection{Surgery and Liver-Directed Therapies}

Until recently, most surgical series of NEN G-3 have included a heterogeneous population of patients with well and poorly differentiated tumors, making it hard to draw firm conclusions. Despite this issue, European and American guidelines recommend surgical resection irrespective of tumor grade and differentiation in the non-metastatic setting [74-80]. Surgery can also be performed in well-differentiated NET G-1 and G-2 after neoadjuvant therapeutic approach in patients with important initial tumor burden (locally advanced tumor or large resection needed), or in the presence of metastasis. The overall prognosis is mainly based on tumor burden (especially in the presence of liver metastasis), cell differentiation and proliferation rate, but also initial tumor site (risk of occlusion in midgut NET).

One study on 28 patients operated for PanNEN G-3 suggested that patients with NET G-3 have similar postoperative survival compared to those with NEC, which was significantly lower than for NET G-2 and G-1 patients [81]. This is contradictory with current knowledge on NET G-3 prognosis and these results could be explained by the pooled evaluation of both localized and metastatic tumors $[3,26,67,82]$. Although surgery is recommended in the non-metastatic setting, we need to keep in mind that high-grade is 
associated with higher risk of recurrence and disease specific-death, as shown recently on a series of operated PanNEN [83].

Liver-directed therapies can be performed alone or in combination with surgery. Indeed, they have shown good clinical and morphological responses for well-differentiated G-1 and G-2 NET, especially when liver burden is important or in the presence of a secretory syndrome. To date, there is no specific data for this therapeutic approach in NET G-3 [84,85].

Although data on surgery in NET G-3 are scarce, it is still considered as the first valid option in the localized setting for all well-differentiated NET. It should be individually discussed for metastatic NET G-3 patients in the context of other available therapeutic approaches such as chemotherapy. Liver-directed therapies should also be discussed individually and in case of important secretory syndrome.

\subsection{Somatostatine Analogues and Targeted Therapies}

Both PROMID and CLARINET prospective trials have validated the anti-proliferative effect of somatostatine analogues (SST) in GEP-NET G-1 and G-2 [86-88]. They are mainly used for indolent well-differentiated NET in the first-line setting and for treatment of the secretory syndrome $[78,79]$. Both studies also showed that SST have a higher efficacy in tumors with low Ki-67 index, low hepatic load and slow pretreatment growth [50-52]. There were no G-3 lesions included in these trials so the use of SST in this population should be limited and only considered with a close monitoring for its effect on the secretory syndrome.

Targeted therapies are mainly used for the treatment of advanced well-differentiated NET. The European Neuroendocrine Tumors Society (ENETS) guidelines recommend them in both first or second-line settings when chemotherapy is not appropriate [89]. In advanced PanNET G-1 and G-2, sunitinib [90], a tyrosine kinase inhibitor, and everolimus [91], a mTOR inhibitor, have both demonstrated efficacy in randomized phase III studies. Regarding advanced non-pancreatic NET, everolimus has shown some efficacy in the RADIANT 2 trial with results later confirmed by the RADIANT 4 trial [92,93]. One work on a small sample of high-grade NEN, including at least six NET G-3 patients, has shown evidence of sunitinib activity [94]. Four out of six patients had partial response or stabilization of the disease under treatment [94]. In one study of 15 patients with "well-moderately" differentiated PanNEN G-3 tumors, administration of everolimus as first-line treatment showed sustained disease stabilization for three out of four patients [95]. The EVINEC phase II trial has evaluated the safety and tolerability of everolimus as second-line treatment in NEC and NET G-3, but results are not yet available (NTC02113800). Recently, surufatinib, a novel multi-target inhibitor, has shown positive effects in progression-free survival (PFS) for extra-pancreatic NET of low and intermediate grades vs. placebo, with no data in NET G-3 [96]. Overall, results with everolimus and sunitinib in NET G-3 need confirmation in larger populations and cannot currently be proposed as first-line treatment.

\subsection{Chemotherapy}

Chemotherapy is a key treatment in metastatic PanNET irrespective of grade. It is commonly prescribed in the first-line setting for "aggressive" metastatic PanNET or in case of failure of previous therapies. Multiple combinations of chemotherapy regimen have been validated in G-1 and G-2 PanNET such as streptozotocin/doxorubicin [97], 5-fluorouracil/streptozotocin [97], LV5 FU2/dacarbazine [98] and capecitabine/ temozolomide $[99,100]$. The addition of bevacizumab to a 5-fluorouracil/streptozotocin combination showed a significant disease control rate (DCR) (56\% of partial responses and $44 \%$ of stabilizations) in the BETTER trial [101]. Irinotecan with 5-fluorouracil (FOLFIRI) can also be been considered as an option in second-line treatment of PanNET [102]. Finally, other combinations of chemotherapies such as capecitabine and oxaliplatine (XELOX), or gemcitabine and oxaliplatine (GEMOX) have also shown effective results in PanNET $[103,104]$. 
In non-pancreatic metastatic NET, there is no standard of care regarding chemotherapy $[78,79]$. Various regimens have been evaluated with studies showing low response rates, especially with alkylant-based treatments [105-107]. This could be the result of the strong expression of $\mathrm{O}_{6}$-methylguanine DNA methyltransferase (MGMT) in these tumors [108]. Cassier et al. suggested that GEMOX had some efficacy in pre-treated nonpancreatic NET G-1 and G-2 patients, with an 84\% overall response rate (ORR) [109]. The best results regarding chemotherapy were obtained with the BETTER trial evaluating the capecitabine/bevacizumab combination: in 49 chemotherapy-naïve patients treated, there was an ORR of $88 \%$ and a PFS of about 23 months [110].

In metastatic NEC from all sites, the recommended first-line chemotherapy is the combination of platinum derivatives (cisplatin or carboplatine) with etoposide [111,112]. A combination of irinotecan and cisplatin can also be proposed, following the results of a Japanese study [113]. FOLFIRI or the association of 5-fluorouracil and oxaliplatine (FOLFOX) can be administered in the second-line setting $[114,115]$. One study has also suggested some efficacy of second-line temozolomide-based regimen in digestive NEC, with $71 \%$ of response (partial response or stabilization). A trial is currently ongoing comparing platinum-based chemotherapy to temozolomide-based chemotherapy in the NEC population (NCT02595424) [116].

In metastatic NET G-3 the efficacy of platinum-based chemotherapy seems limited, with response rates ranging from $0 \%$ to $10 \%$. Two studies reported both $0 \%$ objective response rate to platinum-based chemotherapy in their NET G-3 patients [4,6]. Similarly, in Heetfeld et al. study, the response rate to platinum-based chemotherapy was $2 \%$ in NET G-3 patients vs. 39\% in NEC patients [3]. In another series of 16 patients with PanNET G-3 the response rate to platinum agents was 10\% [26]. In PanNEN G-3 patients from the NORDIC study there was a higher response to platinum-based regimen for patients with Ki-67 index $>55 \%$ ( $42 \%$ vs. $15 \%$ ), suggesting that aggressive lesions respond better to this regimen [57]. On the opposite, results with alkylant agents are more encouraging in NET G-3 patients. In the 16 patients with PanNET G-3 from Raj et al. study, the response rate with alkylant-based chemotherapy was 50\% [26]. Furthermore, a monocentric study on G-2 and G-3 NEN from various sites (including 11 NET G-3 patients) evaluated the effect of capecitabine-temozolomide (CAPTEM) with $22 \%$ patients treated in the first line setting [117]. There was a trend towards improved median PFS in patients with NET G-3 and Ki-67 index $<55 \%$ (15 vs. 4 months, $p=0.117$ ) and for patients who received CAPTEM as first-line therapy (17 months vs. 8 months, $p=0.3)$ [117]. Toxicity with CAPTEM regimen was manageable $[117,118]$. Similarly, other studies have found positive results with the CAPTEM regimen in small samples of NET G-3 [119-121].

All of these results suggest that the choice of chemotherapy regimen in metastatic PanNET G-3 should be in line with NET G-2 rather than NEC, especially when Ki-67 index $<55 \%$. Platinum-based regimen can be proposed after individual discussion only. In non-pancreatic NET G-3, no chemotherapy regimen should be considered as a standard of first-line care considering the very small amount of data available.

\subsection{Peptide Receptor Radionuclide Therapy (PRRT)}

The efficacy of PRRT (Lutetium-177 $\left({ }^{177} \mathrm{Lu}\right)$-Dotatate) combined with SST was proven in the prospective phase III NETTER-1 study in 229 patients with advanced well-differentiated midgut NET [122]. The study showed a benefit in PFS at 20 months and in response rate, compared with the control group [122]. Positive results with PRRT are also found in PanNET G-1 and G-2 [123]. Furthermore, a phase I study assessing the efficacy and safety of a novel SST antagonist $\left({ }^{177} \mathrm{Lu}\right)$-satoreotide tetraxetan has shown promising results in 20 patients with well-differentiated NET (including one patient with NET G-3) [124].

As previously described, NET G-3 patients are more likely to show positive SRI uptake than NEC patients. PRRT has been proposed for high-grade NEN patients showing foci anatomical agreement of the SRI and glucose uptake lesions (little mismatch). Recent data are in favor of PRRT efficacy in the second or third-line settings for high-grade GEP-NEN. A 
review of four studies with at least 10 NEN G-3 patients treated with PRRT showed promising response rates (31-41\%) and disease control rates (69-78\%) in this population [125]. Both PFS (11-16 months) and OS (22-46 months) were best for patients with Ki-67 index $<55 \%$ [125]. Even if there were some differences between the four considered studies, they all showed that about two thirds of the pooled population of NEN G-3 had a potential to respond to PRRT. In Carlsen et al. study in 149 NEN G-3 patients treated with PRRT, including at least 60 NET G-3 patients, response rates did not differ among subgroups (including differentiation) [126]. Median PFS and OS were significantly longer for patients with Ki-67 index $<55 \%$ and well-differentiated tumors $(p<0.001)$ [126]. Recently, the combination of PRRT and chemotherapy has been evaluated in advanced G-2 and G-3 NEN. One study found that CAPTEM combined with PRRT had significant activity with mild toxicities in a population including eight NEN G-3 and showing positive dual tracer expression [121].

These results suggest that, for carefully selected patients, PRRT should be considered after first-line treatment for both NET G-3 and NEC with increased uptake on SRI and little mismatch, especially when Ki-67 index <55\% [127]. In this sense, dual tracer using ${ }^{18}$ F-FDG PET-CT and SRI can provide important information for NET G-3 selection for PRRT $[125,128]$.

\subsection{Immunotherapy}

As for other types of malignancies, immune checkpoint inhibitors (ICI) have been considered in NEN treatment. The KEYNOTE-158 trial showed that pembrolizumab had limited antitumor activity in previously treated advanced NET G-1 and G-2 from various sites, with an ORR of 3.7\% (95\%CI, 1.0-9.3) [129]. Some case reports have described treatment response or long survivals in high-grade NEN patients treated with ICI, suggesting that they are a more promising treatment option in this population [130]. For instance, programmed-death-1 blockage has shown positive results in both first and second-line treatment of Merkel cell carcinoma, a high-grade cutaneous NEC [131,132]. Efficacy of ICI in high-grade NEN could be explained by microsatellite instability, and/or high mutational load, which are more frequent in these tumors. Nevertheless, recent data showed that pembrolizumab alone had limited effect in NEN G-3 patients, with a DCR of 24.1\% [133]. Several phase II studies investigating the effect of ICI in patients with advanced high-grade NEN, including NET G-3, are still ongoing. Avelumab is currently evaluated in advanced well-differentiated NET G-2/G-3 (NCT03278379) as well as in progressive NEC/NET G-3 after chemotherapy (NCT03352934). Finally, the combination of durvalumab and tremelimumab is being investigated in GEP-NEN G-3 after progression to previous therapies (NCT03095274). Further studies might also investigate the combination of ICI and chemotherapy or other treatment in the therapeutic management of NEN G-3. Up to this day, ICI for NET G-3 can only be proposed in clinical trials.

\section{Conclusions and Perspectives}

NET G-3 are rare tumors showing specific features of clinical interest. Their prognosis seems closer to that of NET G-2 rather than that of NEC, but with a worse OS. If in doubt, pathologic reassessment by a NEN expert should be easily proposed, especially for pancreatic lesions where NET G-3 more often arise. Due to their rarity and the specific management they require, NET G-3 treatment should always be discussed in NEN expert meetings. Functional imaging plays a crucial role in both diagnosis and treatment management of NEN, and dual tracer imaging should easily be proposed for NET G-3 patients. To this date, available treatments include mainly surgery and chemotherapy with alkylant-based regimen and sometimes platinum-based regimen (most of the data coming from pancreatic series). There are promising results with targeted therapies and PRRT which need confirmation in larger populations. Trials with ICI are still ongoing, and the combination of chemotherapy and ICI should be explored in the future for more antitumoral activity. Based on the available literature and on the 2020 European recommen- 
dations, we propose the following algorithm for the therapeutic management of digestive NET G-3 [127] (Figure 3).

\section{Grade 3 Well-differentiated neuroendocrine tumors} (NET G-3)

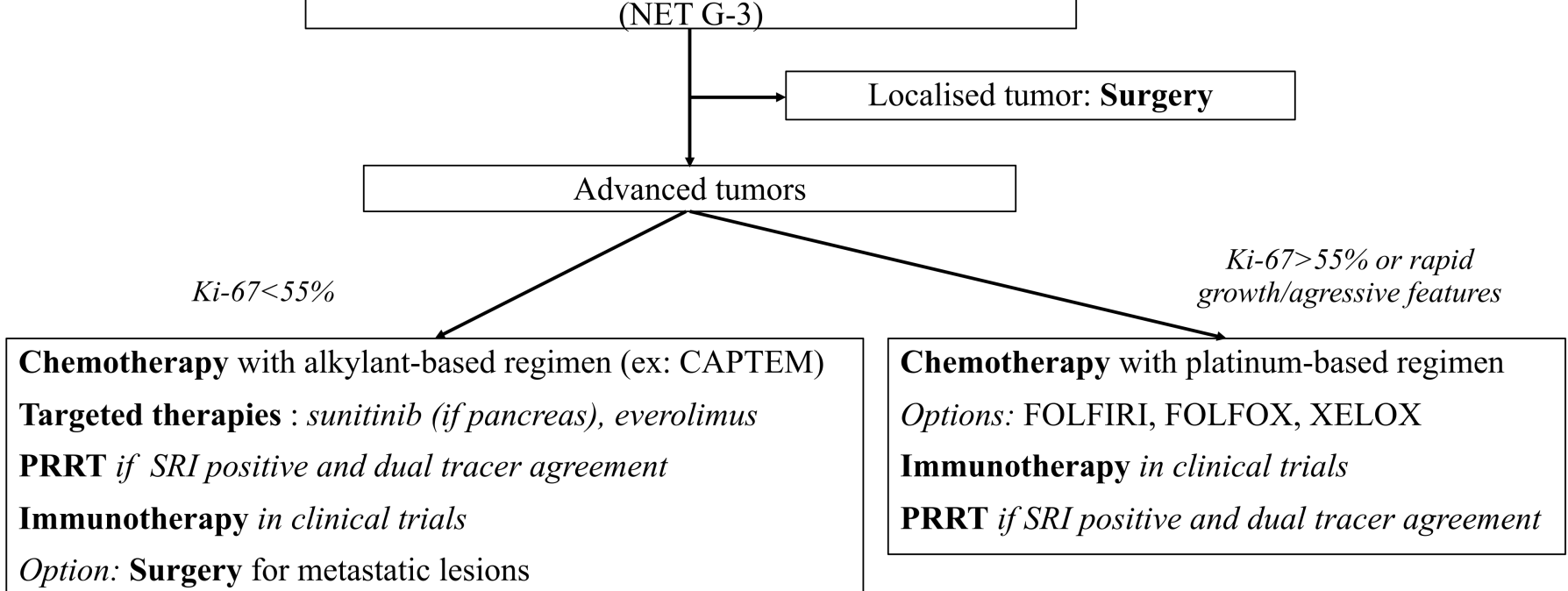

Cardinoid syndrome:

Option: Somatostatine analogues

Option: Liver-directed therapies (chemoembolization, embolization)

Figure 3. Proposed treatment algorithm for the therapeutic management of grade 3 well-differentiated neuroendocrine tumors (NET G-3). CAPTEM: capecitabine + temozolomide, FOLFIRI: 5-fluorouracile + irinotecan, FOLFOX: 5-fluorouracile + oxaliplatine, XELOX: capecitabine + oxaliplatine, PRRT: peptide receptor radionuclide therapy, SRI: somatostatin receptor imaging.

Currently, molecular biology and theranostics seem the two most promising fields of research to help individualize and standardize treatment for NET G-3. Whole genomic sequencing of PanNET G-3 samples could help identify new structural rearrangements or mutations. Data in molecular biology is also urgently needed in non-pancreatic NET G-3. Other diagnostic tools, such as the NET test, a multianalyte liquid biopsy measuring NET gene expression, might also help individualize NET G-3 in the future. Finally, dual tracer imaging should always be discussed in patients with NET G-3 to help select patients for PRRT.

Overall, it is important to highlight that our review has limitations due to the scarcity of available studies for this newly introduced entity. Additionally, the population samples are very small. Therefore, the main conclusions on NET G-3 characteristics and specific treatment will need to be confirmed in future larger trials. In order to deal with recruitment difficulty due to the rarity of these tumors, international collaborations should be encouraged.

Author Contributions: Conceptualization, A.P. and R.C.; methodology, A.P.; writing-original draft preparation, A.P.; writing-review and editing, A.P., P.S, A.S.C., R.C., U.M., L.-J.P., C.B.; supervision, R.C. and P.S. All authors have read and agreed to the published version of the manuscript.

Funding: This research received no external funding.

Institutional Review Board Statement: Ethical review and approval were waived for this review due to its descriptive nature and the exclusive use of previously published data.

Informed Consent Statement: Information on patient consent was found in previously published articles when available. 
Data Availability Statement: This narrative review is based on previously published data.

Conflicts of Interest: The authors declare no conflict of interest for this work.

\section{References}

1. Baudin, E. Gastroenteropancreatic endocrine tumors: Clinical characterization before therapy. Nat. Clin. Pract. Endocrinol. Metab. 2007, 3, 228-239. [CrossRef] [PubMed]

2. Klöppel, G. Neuroendocrine neoplasms: Dichotomy, origin and classifications. Visc. Med. 2017, 33, 324-330. [CrossRef] [PubMed]

3. Heetfeld, M.; Chougnet, C.N.; Olsen, I.H.; Rinke, A.; Borbath, I.; Crespo, G.; Barriuso, J.; Pavel, M.; O’Toole, D.; Walter, T.; et al. Characteristics and treatment of patients with G3 gastroenteropancreatic neuroendocrine neoplasms. Endocr. Relat. Cancer 2015, 22, 657-664. [CrossRef] [PubMed]

4. Hijioka, S.; Hosoda, W.; Matsuo, K.; Ueno, M.; Furukawa, M.; Yoshitomi, H.; Kobayashi, N.; Ikeda, M.; Ito, T.; Nakamori, S.; et al. Rb loss and KRAS mutation are predictors of the response to platinum-based chemotherapy in pancreatic neuroendocrine neoplasm with grade 3: A japanese multicenter pancreatic NEN-G3 study. Clin. Cancer Res. 2017, 23, 4625-4632. [CrossRef] [PubMed]

5. Nagtegaal, I.D.; Odze, R.D.; Klimstra, D.; Paradis, V.; Rugge, M.; Schirmacher, P.; Washington, K.M.; Carneiro, F.; Cree, I.A.; WHO Classification of Tumours Editorial Board. The 2019 WHO classification of tumours of the digestive system. Histopathology 2020, 76, 182-188. [CrossRef]

6. Velayoudom-Cephise, F.L.; Duvillard, P.; Foucan, L.; Hadoux, J.; Chougnet, C.N.; Leboulleux, S.; Malka, D.; Guigay, J.; Goere, D.; Debaere, T.; et al. Are G3 ENETS neuroendocrine neoplasms heterogeneous? Endocr. Relat. Cancer 2013, 20, 649-657. [CrossRef]

7. Basturk, O.; Yang, Z.; Tang, L.H.; Hruban, R.H.; Adsay, V.; McCall, C.M.; Krasinskas, A.M.; Jang, K.T.; Frankel, W.L.; Balci, S.; et al. The high-grade (WHO G3) pancreatic neuroendocrine tumor category is morphologically and biologically heterogenous and includes both well differentiated and poorly differentiated neoplasms. Am. J. Surg. Pathol. 2015, 39, 683-690. [CrossRef]

8. Fazio, N.; Milione, M. Heterogeneity of grade 3 gastroenteropancreatic neuroendocrine carcinomas: New insights and treatment implications. Cancer Treat. Rev. 2016, 50, 61-67. [CrossRef] [PubMed]

9. Perren, A.; Couvelard, A.; Scoazec, J.-Y.; Costa, F.; Borbath, I.; Delle Fave, G.; Gorbounova, V.; Gross, D.; Grossma, A.; Jense, R.T.; et al. ENETS consensus guidelines for the standards of care in neuroendocrine tumors: Pathology: Diagnosis and prognostic stratification. Neuroendocrinology 2017, 105, 196-200. [CrossRef]

10. Rindi, G.; Klimstra, D.S.; Abedi-Ardekani, B.; Asa, S.L.; Bosman, F.T.; Brambilla, E.; Busam, K.J.; de Krijger, R.R.; Dietel, M.; El-Naggar, A.K.; et al. A common classification framework for neuroendocrine neoplasms: An International Agency for Research on Cancer (IARC) and World Health Organization (WHO) expert consensus proposal. Mod. Pathol. 2018, 31, 1770-1786. [CrossRef]

11. Pellat, A.; Wislez, M.; Svrcek, M.; Hammel, P.; Afchain, P.; Andre, T. Therapeutic management of poorly differentiated neuroendocrine lung tumors and neuroendocrine carcinomas of the digestive system. Bull. Cancer 2016, 103, 880-895. [CrossRef] [PubMed]

12. Yao, J.C.; Hassan, M.; Phan, A.; Dagohoy, C.; Leary, C.; Mares, J.E.; Abdalla, E.K.; Fleming, J.B.; Vauthey, J.N.; Rashid, A.; et al. One hundred years after "carcinoid": Epidemiology of and prognostic factors for neuroendocrine tumors in 35,825 cases in the United States. J. Clin. Oncol. 2008, 26, 3063-3072. [CrossRef]

13. Strosberg, J.R.; Cheema, A.; Weber, J.; Han, G.; Coppola, D.; Kvols, L.K. Prognostic validity of a novel american joint committee on cancer staging classification for pancreatic neuroendocrine tumors. J. Clin. Oncol. 2011, 29, 3044-3049. [CrossRef] [PubMed]

14. Coriat, R.; Walter, T.; Terris, B.; Couvelard, A.; Ruszniewski, P. Gastroenteropancreatic well-differentiated grade 3 neuroendocrine tumors: Review and position statement. Oncologist 2016, 21, 1191-1199. [CrossRef]

15. Pellat, A.; Coriat, R. Well differentiated grade 3 neuroendocrine tumors of the digestive tract: A narrative review. J. Clin. Med. 2020, 9, 1677. [CrossRef]

16. Jensen, R.T.; Bodei, L.; Capdevila, J.; Couvelard, A.; Falconi, M.; Glasberg, S.; Kloppel, G.; Lamberts, S.; Peeters, M.; Rindi, G.; et al. Unmet needs in functional and nonfunctional pancreatic neuroendocrine neoplasms. Neuroendocrinology 2019, 108, 26-36. [CrossRef]

17. Leoncini, E.; Boffetta, P.; Shafir, M.; Aleksovska, K.; Boccia, S.; Rindi, G. Increased incidence trend of low-grade and high-grade neuroendocrine neoplasms. Endocrine 2017, 58, 368-379. [CrossRef]

18. Niederle, M.B.; Hackl, M.; Kaserer, K.; Niederle, B. Gastroenteropancreatic neuroendocrine tumours: The current incidence and staging based on the WHO and European Neuroendocrine Tumour Society Classification: An analysis based on prospectively collected parameters. Endoc. Relat. Cancer 2010, 17, 909-918. [CrossRef]

19. Korse, C.M.; Taal, B.G.; van Velthuysen, M.L.; Visser, O. Incidence and survival of neuroendocrine tumours in the Netherlands according to histological grade: Experience of two decades of cancer registry. Eur. J. Cancer 2013, 49, 1975-1983. [CrossRef]

20. Walter, T.; Tougeron, D.; Baudin, E.; Le Malicot, K.; Lecomte, T.; Malka, D.; Hentic, O.; Manfredi, S.; Bonnet, I.; Guimbaud, R.; et al. Poorly differentiated gastro-entero-pancreatic neuroendocrine carcinomas: Are they really heterogeneous? Insights from the FFCD-GTE national cohort. Eur. J. Cancer 2017, 79, 158-165. [CrossRef]

21. Kim, H.; An, S.; Lee, K.; Ahn, S.; Park, D.Y.; Kim, J.-H.; Kang, D.-W.; Kim, M.-J.; Chang, M.S.; Jung, E.S.; et al. Pancreatic high-grade neuroendocrine neoplasms in the Korean population: A multicenter study. Cancer Res. Treat. 2020, 52, 263-276. [CrossRef] [PubMed] 
22. Scoazec, J.-Y.; Couvelard, A.; Monges, G.; Leteurtre, E.; Belleannee, G.; Guyetant, S.; Duvillard, P.; Danjoux, M.; Parot, X.; Lepage, C. Well-differentiated grade 3 digestive neuroendocrine tumors: Myth or reality? The PRONET study group. J. Clin. Oncol. 2012, 30, 4129. [CrossRef]

23. Scoazec, J.-Y.; Couvelard, A.; Monges, G.; Guyétant, S.; Bisot-Locard, S.; Parot, X.; Lepage, C. Professional practices and diagnostic issues in neuroendocrine tumour pathology: Results of a prospective one-year survey among French pathologists (the PRONET study). Neuroendocrinology 2017, 105, 67-76. [CrossRef] [PubMed]

24. Halfdanarson, T.R.; Rabe, K.G.; Rubin, J.; Petersen, G.M. Pancreatic neuroendocrine rumors (PNETs): Incidence, prognosis and recent Trend toward improved survival. Ann. Oncol. 2008, 19, 1727-1733. [CrossRef]

25. Ito, T.; Igarashi, H.; Jensen, R.T. Pancreatic neuroendocrine tumors: Clinical features, diagnosis and medical treatment: Advances. Best Pract. Res. Clin. Gastroenterol. 2012, 26, 737-753. [CrossRef] [PubMed]

26. Raj, N.; Valentino, E.; Capanu, M.; Tang, L.H.; Basturk, O.; Untch, B.R.; Allen, P.J.; Klimstra, D.S.; Reidy-Lagunes, D. Treatment response and outcomes of grade 3 pancreatic neuroendocrine neoplasms based on morphology: Well differentiated versus poorly differentiated. Pancreas 2017, 46, 296-301. [CrossRef]

27. Sigel, C.S.; Krauss Silva, V.W.; Reid, M.D.; Chhieng, D.; Basturk, O.; Sigel, K.M.; Daniel, T.D.; Klimstra, D.S.; Tang, L.H. Well differentiated grade 3 pancreatic neuroendocrine tumors compared with related neoplasms: A morphologic study. Cancer Cytopathol. 2018, 126, 326-335. [CrossRef]

28. Lawrence, B.; Gustafsson, B.I.; Chan, A.; Svejda, B.; Kidd, M.; Modlin, I.M. The epidemiology of gastroenteropancreatic neuroendocrine tumors. Endocrinol. Metab. Clin. N. Am. 2011, 40, 1-18. [CrossRef]

29. Korse, C.M.; Taal, B.G.; Vincent, A.; van Velthuysen, M.-L.F.; Baas, P.; Buning-Kager, J.C.G.M.; Linders, T.C.; Bonfrer, J.M.G. Choice of tumour markers in patients with neuroendocrine tumours is dependent on the histological grade. A marker study of chromogranin A, neuron specific enolase, progastrin-releasing peptide and cytokeratin fragments. Eur. J. Cancer 2012, 48, 662-6712. [CrossRef]

30. Oberg, K.; Couvelard, A.; Delle Fave, G.; Gross, D.; Grossman, A.; Jensen, R.T.; Pape, U.-F.; Perren, A.; Rindi, G.; Ruszniewski, P.; et al. ENETS consensus guidelines for standard of care in neuroendocrine tumours: Biochemical markers. Neuroendocrinology 2017, 105, 201-211. [CrossRef]

31. Baudin, E.; Gigliotti, A.; Ducreux, M.; Ropers, J.; Comoy, E.; Sabourin, J.C.; Bidart, J.M.; Cailleux, A.F.; Bonacci, R.; Ruffié, P.; et al. Neuron-specific enolase and chromogranin A as markers of neuroendocrine tumours. Br. J. Cancer 1998, 78, $1102-1107$. [CrossRef] [PubMed]

32. Lv, Y.; Han, X.; Zhang, C.; Fang, Y.; Pu, N.; Ji, Y.; Wang, D.; Xuefeng, X.; Lou, W. Combined test of serum CgA and NSE improved the power of prognosis prediction of NF-PNETs. Endocr. Connect. 2018, 7, 169-178. [CrossRef] [PubMed]

33. Meijer, W.G.; Kema, I.P.; Volmer, M.; Willemse, P.H.; de Vries, E.G. Discriminating capacity of indole markers in the diagnosis of carcinoid tumors. Clin. Chem. 2000, 46, 1588-1596. [CrossRef] [PubMed]

34. Ali, A.S.; Perren, A.; Lindskog, C.; Welin, S.; Sorbye, H.; Grönberg, M.; Janson, E.T. Candidate protein biomarkers in pancreatic neuroendocrine neoplasms grade 3. Sci. Rep. 2020, 10, 10639. [CrossRef]

35. Chen, H.-Y.; Zhang, X.-Y.; Deng, X.-Y.; Ge, Y.-L.; Tang, Y.-Q.; Cui, H.; Yang, B.; Pan, Y.; Shi, D.; Yu, R.-S. Grade 3 pancreatic neuroendocrine tumors on MDCT: Establishing a diagnostic model and comparing survival against pancreatic ductal adenocarcinoma. AJR Am. J. Roentgenol. 2020, 215, 390-397. [CrossRef]

36. Sorbye, H.; Strosberg, J.; Baudin, E.; Klimstra, D.S.; Yao, J.C. Gastroenteropancreatic high-grade neuroendocrine carcinoma. Cancer 2014, 120, 2814-2823. [CrossRef]

37. Genc, C.G.; Klümpen, H.J.; van Oijen, M.G.H.; van Eijck, C.H.J.; Nieveen van Dijkum, E.J.M. A nationwide population-based study on the survival of patients with pancreatic neuroendocrine tumors in the Netherlands. World J. Surg. 2018, 42, $490-497$. [CrossRef]

38. Folkert, I.W.; Sinnamon, A.J.; Concors, S.J.; Bennett, B.J.; Fraker, D.L.; Mahmoud, N.N.; Metz, D.C.; Stashek, K.M.; Roses, R.E. Grade is a dominant risk factor for metastasis in patients with rectal neuroendocrine tumors. Ann. Surg. Oncol. 2020, $27,855-863$. [CrossRef]

39. Milione, M.; Maisonneuve, P.; Spada, F.; Pellegrinelli, A.; Spaggiari, P.; Albarello, L.; Pisa, E.; Barberis, M.; Vanoli, A.; Buzzoni, R.; et al. The clinicopathologic heterogeneity of grade 3 gastroenteropancreatic neuroendocrine neoplasms: Morphological differentiation and proliferation identify different prognostic categories. Neuroendocrinology 2017, 104, 85-93. [CrossRef]

40. Yordanova, A.; Biersack, H.-J.; Ahmadzadehfar, H. Advances in molecular imaging and radionuclide therapy of neuroendocrine tumors. J. Clin. Med. 2020, 9, 3679. [CrossRef]

41. Zhang, J.; Liu, Q.; Singh, A.; Schuchardt, C.; Kulkarni, H.R.; Baum, R.P. Prognostic value of 18F-FDG PET/CT in a large cohort of patients with advanced metastatic neuroendocrine neoplasms treated with Peptide Receptor Radionuclide Therapy. J. Nucl. Med. 2020, 61, 1560-1569. [CrossRef]

42. Binderup, T.; Knigge, U.; Loft, A.; Federspiel, B.; Kjaer, A. 18F-Fluorodeoxyglucose positron emission tomography predicts survival of patients with neuroendocrine tumors. Clin. Cancer Res. 2010, 16, 978-985. [CrossRef]

43. Bahri, H.; Laurence, L.; Edeline, J.; Leghzali, H.; Devillers, A.; Raoul, J.-L.; Cuggia, M.; Mesbah, H.; Clement, B.; Boucher, E.; et al. High prognostic value of 18F-FDG PET for metastatic gastroenteropancreatic neuroendocrine tumors: A long-term evaluation. J. Nucl. Med. 2014, 55, 1786-1790. [CrossRef] 
44. Hindié, E. The NETPET score: Combining FDG and somatostatin receptor imaging for optimal management of patients with metastatic well-differentiated neuroendocrine tumors. Theranostics 2017, 7, 1159-1163. [CrossRef]

45. Chan, D.L.; Pavlakis, N.; Schembri, G.P.; Bernard, E.J.; Hsiao, E.; Hayes, A.; Barnes, T.; Diakos, C.; Khasraw, M.; Samra, J.; et al. Dual somatostatin receptor/FDG PET/CT imaging in metastatic neuroendocrine tumours: Proposal for a novel grading scheme with prognostic significance. Theranostics 2017, 7, 1149-1158. [CrossRef]

46. Zhang, P.; Yu, J.; Li, J.; Shen, L.; Li, N.; Zhu, H.; Zhai, S.; Zhang, Y.; Yang, Z.; Lu, M. Clinical and prognostic value of PET/CT imaging with combination of 68Ga-DOTATATE and 18F-FDG in gastroenteropancreatic neuroendocrine neoplasms. Contrast Media Mol. Imaging 2018, 2018, 2340389. [CrossRef]

47. Chan, H.; Moseley, C.; Zhang, L.; Bergsland, E.K.; Pampaloni, M.H.; Van Loon, K.; Hope, T.A. Correlation of DOTATOC uptake and pathologic grade in neuroendocrine tumors. Pancreas 2019, 48, 948-952. [CrossRef]

48. Waseem, N.; Aparici, C.M.; Kunz, P.L. Evaluating the role of theranostics in grade 3 neuroendocrine neoplasms. J. Nucl. Med. 2019, 60, 882-891. [CrossRef] [PubMed]

49. Werner, R.A.; Weich, A.; Higuchi, T.; Schmid, J.S.; Schirbel, A.; Lassmann, M.; Wild, V.; Rudelius, M.; Kudlich, T.; Herrmann, K.; et al. Imaging of chemokine receptor 4 expression in neuroendocrine tumors-a triple tracer comparative approach. Theranostics 2017, 7, 1489-1498. [CrossRef]

50. Sawicki, L.M.; Deuschl, C.; Beiderwellen, K.; Ruhlmann, V.; Poeppel, T.D.; Heusch, P.; Lahner, H.; Führer, D.; Bockisch, A.; Herrmann, K.; et al. Evaluation of 68Ga-DOTATOC PET/MRI for whole-body staging of neuroendocrine tumours in comparison with 68Ga-DOTATOC PET/CT. Eur. Radiol. 2017, 27, 4091-4099. [CrossRef] [PubMed]

51. Canellas, R.; Burk, K.S.; Parakh, A.; Sahani, D.V. Prediction of pancreatic neuroendocrine tumor grade based on CT features and texture analysis. AJR Am. J. Roentgenol. 2018, 210, 341-346. [CrossRef] [PubMed]

52. Choi, T.W.; Kim, J.H.; Yu, M.H.; Park, S.J.; Han, J.K. Pancreatic neuroendocrine tumor: Prediction of the tumor grade using CT findings and computerized texture analysis. Acta Radiol. 2018, 59, 383-392. [CrossRef] [PubMed]

53. Guo, C.; Zhuge, X.; Wang, Z.; Wang, Q.; Sun, K.; Feng, Z.; Chen, X. Textural analysis on contrast-enhanced CT in pancreatic neuroendocrine neoplasms: Association with WHO grade. Abdom. Radiol. 2019, 44, 576-585. [CrossRef] [PubMed]

54. Azoulay, A.; Cros, J.; Vullierme, M.-P.; de Mestier, L.; Couvelard, A.; Hentic, O.; Ruszniewski, P.; Sauvanet, A.; Vilgrain, V.; Ronot, M. Morphological imaging and CT histogram analysis to differentiate pancreatic neuroendocrine tumor grade 3 from neuroendocrine carcinoma. Diagn. Interv. Imaging 2020, 101, 821-830. [CrossRef]

55. Weisberg, E.M.; Chu, L.C.; Park, S.; Yuille, A.L.; Kinzler, K.W.; Vogelstein, B.; Fishman, E.K. Deep lessons learned: Radiology, oncology, pathology, and computer science experts unite around artificial intelligence to strive for earlier pancreatic cancer diagnosis. Diagn. Interv. Imaging 2020, 101, 111-115. [CrossRef]

56. Bartoli, M.; Barat, M.; Dohan, A.; Gaujoux, S.; Coriat, R.; Hoeffel, C.; Cassinotto, C.; Chassagnon, G.; Soyer, P. CT and MRI of pancreatic tumors: An update in the era of radiomics. Jpn. J. Radiol. 2020, 38, 1111-1124. [CrossRef]

57. Sorbye, H.; Welin, S.; Langer, S.W.; Vestermark, L.W.; Holt, N.; Osterlund, P.; Dueland, S.; Hofsli, E.; Guren, M.G.; Ohrling, K.; et al. Predictive and prognostic factors for treatment and survival in 305 patients with advanced gastrointestinal neuroendocrine carcinoma (WHO G3): The NORDIC NEC study. Ann. Oncol. 2013, 24, 152-160. [CrossRef]

58. Shi, H.; Chen, L.; Zhang, Q.; Lin, Y.; Jiang, C.; Yao, H.; Hou, X.; Chen, M.; Lin, R.; Chen, J. Concordance between the Ki-67 index cutoff value of $55 \%$ and differentiation in neuroendocrine tumor and neuroendocrine carcinoma in grade 3 pancreatic neuroendocrine neoplasms. Pancreas 2020, 49, 1378-1382. [CrossRef] [PubMed]

59. Weynand, B.; Borbath, I.; Bernard, V.; Sempoux, C.; Gigot, J.-F.; Hubert, C.; Lannoy, V.; Deprez, P.H.; Jouret-Mourin, A. Pancreatic neuroendocrine tumour grading on endoscopic ultrasound-guided fine needle aspiration: High reproducibility and inter-observer agreement of the Ki-67 labelling index. Cytopathology 2014, 25, 389-395. [CrossRef]

60. Kalantri, S.; Bakshi, P.; Verma, K. Grading of pancreatic neuroendocrine tumors on endoscopic ultrasound-guided fine-needle aspiration using Ki-67 index and 2017 World Health Organization criteria: An analysis of 32 cases. Cytojournal 2020, 17, 21. [CrossRef]

61. Tang, L.H.; Untch, B.R.; Reidy, D.L.; O’Reilly, E.; Dhall, D.; Jih, L.; Basturk, O.; Allen, P.J.; Klimstra, D.S. Well-differentiated neuroendocrine tumors with a morphologically apparent high-grade component: A pathway distinct from poorly differentiated neuroendocrine carcinomas. Clin. Cancer Res. 2016, 22, 1011-1017. [CrossRef] [PubMed]

62. Reid, M.D.; Bagci, P.; Ohike, N.; Saka, B.; Erbarut Seven, I.; Dursun, N.; Balci, S.; Gucer, H.; Jang, K.-T.; Tajiri, T.; et al. Calculation of the Ki67 Index in pancreatic neuroendocrine tumors: A comparative analysis of four counting methodologies. Mod. Pathol. 2015, 28, 686-694. [CrossRef]

63. Van Velthuysen, M.-L.F.; Groen, E.J.; Sanders, J.; Prins, F.A.; van der Noort, V.; Korse, C.M. Reliability of proliferation assessment by Ki-67 expression in neuroendocrine neoplasms: Eyeballing or image analysis? Neuroendocrinology 2014, 100, 288-292. [CrossRef] [PubMed]

64. Botling, J.; Lamarca, A.; Bajic, D.; Norlén, O.; Lönngren, V.; Kjaer, J.; Eriksson, B.; Welin, S.; Hellman, P.; Rindi, G.; et al. Highgrade progression confers poor survival in pancreatic neuroendocrine tumors. Neuroendocrinology 2020, 110, 891-898. [CrossRef] [PubMed]

65. Sorbye, H.; Baudin, E.; Perren, A. The problem of high-grade gastroenteropancreatic neuroendocrine neoplasms: Welldifferentiated neuroendocrine tumors, neuroendocrine carcinomas, and beyond. Endocrinol. Metab. Clin. N. Am. 2018, 47, 683-698. [CrossRef] [PubMed] 
66. Yachida, S.; Vakiani, E.; White, C.M.; Zhong, Y.; Saunders, T.; Morgan, R.; de Wilde, R.F.; Maitra, A.; Hicks, J.; Demarzo, A.M.; et al. Small cell and large cell neuroendocrine carcinomas of the pancreas are genetically similar and sistinct from well-differentiated pancreatic neuroendocrine tumors. Am. J. Surg. Pathol. 2012, 36, 173-184. [CrossRef]

67. Tang, L.H.; Basturk, O.; Sue, J.J.; Klimstra, D.S. A practical approach to the classification of WHO grade 3 (G3) well-differentiated neuroendocrine tumor (WD-NET) and poorly differentiated neuroendocrine carcinoma (PD-NEC) of the pancreas. Am. J. Surg. Pathol. 2016, 40, 1192-1202. [CrossRef]

68. Uccella, S.; La Rosa, S.; Metovic, J.; Marchiori, D.; Scoazec, J.-Y.; Volante, M.; Mete, O.; Papotti, M. Genomics of high-grade neuroendocrine neoplasms: Well-differentiated neuroendocrine tumor with high-grade features (G3 NET) and neuroendocrine carcinomas (NEC) of various anatomic sites. Endocr. Pathol. 2021, 32, 192-210. [CrossRef]

69. Koh, J.; Nam, S.K.; Kwak, Y.; Kim, G.; Kim, K.-K.; Lee, B.-C.; Ahn, S.-H.; Park, D.J.; Kim, H.-H.; Park, K.U.; et al. Comprehensive genetic features of gastric mixed adenoneuroendocrine carcinomas and pure neuroendocrine carcinomas. J. Pathol. 2021, 253, 94-105. [CrossRef]

70. Jiao, Y.; Shi, C.; Edil, B.H.; de Wilde, R.F.; Klimstra, D.S.; Maitra, A.; Schulick, R.D.; Tang, L.H.; Wolfgang, C.L.; Choti, M.A.; et al. DAXX/ATRX, MEN1, and MTOR pathway genes are frequently altered in pancreatic neuroendocrine tumors. Science 2011, 331, 1199-1203. [CrossRef]

71. Scarpa, A.; Chang, D.K.; Nones, K.; Corbo, V.; Patch, A.-M.; Bailey, P.; Lawlor, R.T.; Johns, A.L.; Miller, D.K.; Mafficini, A.; et al. Whole-genome landscape of pancreatic neuroendocrine tumours. Nature 2017, 543, 65-71. [CrossRef]

72. Wong, H.-L.; Yang, K.C.; Shen, Y.; Zhao, E.Y.; Loree, J.M.; Kennecke, H.F.; Kalloger, S.E.; Karasinska, J.M.; Lim, H.J.; Mungall, A.J.; et al. Molecular characterization of metastatic pancreatic neuroendocrine tumors (PNETs) using whole-genome and transcriptome sequencing. Cold Spring Harb. Mol. Case Stud. 2018, 4, a002329. [CrossRef]

73. Williamson, L.M.; Steel, M.; Grewal, J.K.; Thibodeau, M.L.; Zhao, E.Y.; Loree, J.M.; Yang, K.C.; Gorski, S.M.; Mungall, A.J.; Mungall, K.L.; et al. Genomic characterization of a well-differentiated grade 3 pancreatic neuroendocrine tumor. Cold Spring Harb Mol. Case Stud. 2019, 5, a003814. [CrossRef] [PubMed]

74. Strosberg, J.R.; Coppola, D.; Klimstra, D.S.; Phan, A.T.; Kulke, M.H.; Wiseman, G.A.; Kvols, L.K.; North American Neuroendocrine Tumor Society (NANETS). The NANETS consensus guidelines for the diagnosis and management of poorly differentiated (highgrade) extrapulmonary neuroendocrine carcinomas. Pancreas 2010, 39, 799-800. [CrossRef] [PubMed]

75. Boudreaux, J.P.; Klimstra, D.S.; Hassan, M.M.; Woltering, E.A.; Jensen, R.T.; Goldsmith, S.J.; Nutting, C.; Bushnell, D.L.; Caplin, M.E.; Yao, J.C.; et al. The NANETS consensus guideline for the diagnosis and management of neuroendocrine tumors: Well-differentiated neuroendocrine tumors of the jejunum, ileum, appendix, and cecum. Pancreas 2010, 39, 753-766. [CrossRef]

76. Falconi, M.; Bartsch, D.K.; Eriksson, B.; Klöppel, G.; Lopes, J.M.; O'Connor, J.M.; Salazar, R.; Taal, B.G.; Vullierme, M.P.; O’Toole, D.; et al. ENETS consensus guidelines for the management of patients with digestive neuroendocrine neoplasms of the digestive system: Well-differentiated pancreatic non-functioning tumors. Neuroendocrinology 2012, 95, 120-134. [CrossRef]

77. Kulke, M.H.; Anthony, L.B.; Bushnell, D.L.; de Herder, W.W.; Goldsmith, S.J.; Klimstra, D.S.; Marx, S.J.; Pasieka, J.L.; Pommier, R.F.; Yao, J.C.; et al. NANETS treatment guidelines: Well-differentiated neuroendocrine tumors of the stomach and pancreas. Pancreas 2010, 39, 735-752. [CrossRef]

78. Pape, U.-F.; Perren, A.; Niederle, B.; Gross, D.; Gress, T.; Costa, F.; Arnold, R.; Denecke, T.; Plöckinger, U.; Salazar, R.; et al. ENETS consensus guidelines for the management of patients with neuroendocrine neoplasms from the jejuno-ileum and the appendix including goblet cell carcinomas. Neuroendocrinology 2012, 95, 135-156.

79. O'Toole, D.; Kianmanesh, R.; Caplin, M. ENETS 2016 consensus guidelines for the management of patients with digestive neuroendocrine tumors: An update. Neuroendocrinology 2016, 103, 117-118. [CrossRef]

80. Garcia-Carbonero, R.; Sorbye, H.; Baudin, E.; Raymond, E.; Wiedenmann, B.; Niederle, B.; Sedlackova, E.; Toumpanakis, C.; Anlauf, M.; Cwikla, J.B.; et al. ENETS consensus guidelines for high-grade gastroenteropancreatic neuroendocrine tumors and neuroendocrine carcinomas. Neuroendocrinology 2016, 103, 186-194. [CrossRef]

81. Worth, P.J.; Leal, J.; Ding, Q.; Trickey, A.; Dua, M.M.; Chatzizacharias, N.; Soonawalla, Z.; Athanasopoulos, P.; Toumpanakis, C.; Hansen, P.; et al. Pancreatic grade 3 neuroendocrine tumors behave similarly to neuroendocrine carcinomas following resection: A multi-center, international appraisal of the WHO 2010 and WHO 2017 staging schema for pancreatic neuroendocrine lesions. HPB 2020, 22, 1359-1367. [CrossRef] [PubMed]

82. De Mestier, L.; Lacombe, C.; Couvelard, A.; Ruszniewski, P.; Cros, J. Could pancreatic grade 3 neuroendocrine tumors really behave similarly to neuroendocrine carcinomas following resection? HPB 2020, 22, 792. [CrossRef] [PubMed]

83. Rosenblum, R.E.; Harris, C.K.; Baeg, K.J.; Starr, J.A.; Brais, L.K.; Stashek, K.M.; Ward, S.C.; Katona, B.W.; Clancy, T.E.; Wisnivesky, J.P.; et al. Predictors of recurrence and survival in patients with surgically resected pancreatic neuroendocrine tumors. Pancreas 2020, 49, 249-254. [CrossRef] [PubMed]

84. Zappa, M.; Abdel-Rehim, M.; Hentic, O.; Vullierme, M.-P.; Ruszniewski, P.; Vilgrain, V. Liver-directed therapies in liver metastases from neuroendocrine tumors of the gastrointestinal tract. Target. Oncol. 2012, 7, 107-116. [CrossRef]

85. De Baere, T.; Deschamps, F.; Tselikas, L.; Ducreux, M.; Planchard, D.; Pearson, E.; Berdelou, A.; Leboulleux, S.; Elias, D.; Baudin, E. GEP-NETS update: Interventional radiology: Role in the treatment of liver metastases from GEP-NETs. Eur. J. Endocrinol. 2015, 172, R151-R166. [CrossRef] 
86. Rinke, A.; Müller, H.-H.; Schade-Brittinger, C.; Klose, K.-J.; Barth, P.; Wied, M.; Mayer, C.; Aminossadati, B.; Pape, U.-F.; Bläker, M.; et al. Placebo-controlled, double-blind, prospective, randomized study on the effect of Octreotide LAR in the control of tumor growth in patients with metastatic neuroendocrine midgut tumors: A report from the PROMID study group. J. Clin. Oncol. 2009, 27, 4656-4663. [CrossRef]

87. Caplin, M.E.; Pavel, M.; Ruszniewski, P. Lanreotide in metastatic enteropancreatic neuroendocrine tumors. N. Engl. J. Med. 2014, 371, 1556-1557. [CrossRef]

88. Palazzo, M.; Lombard-Bohas, C.; Cadiot, G.; Matysiak-Budnik, T.; Rebours, V.; Vullierme, M.-P.; Couvelard, A.; Hentic, O.; Ruszniewski, P. Ki67 proliferation index, hepatic tumor load, and pretreatment tumor growth predict the antitumoral efficacy of lanreotide in patients with malignant digestive neuroendocrine rumors. Eur. J. Gastroenterol. Hepatol. 2013, 25, 232-238. [CrossRef]

89. Pavel, M.; Baudin, E.; Couvelard, A.; Krenning, E.; Öberg, K.; Steinmüller, T.; Anlauf, M.; Wiedenmann, B.; Salazar, R. Barcelona Consensus Conference participants. ENETS consensus guidelines for the management of patients with liver and other distant metastases from neuroendocrine neoplasms of foregut, midgut, hindgut, and unknown primary. Neuroendocrinology 2012, 95, 157-176. [CrossRef]

90. Raymond, E.; Dahan, L.; Raoul, J.-L.; Bang, Y.-J.; Borbath, I.; Lombard-Bohas, C.; Valle, J.; Metrakos, P.; Smith, D.; Vinik, A.; et al. Sunitinib malate for the treatment of pancreatic neuroendocrine tumors. N. Engl. J. Med. 2011, 364, 501-513. [CrossRef]

91. Yao, J.C.; Shah, M.H.; Ito, T.; Bohas, C.L.; Wolin, E.M.; Van Cutsem, E.; Hobday, T.J.; Okusaka, T.; Capdevila, J.; de Vries, E.G.; et al. Everolimus for advanced pancreatic neuroendocrine tumors. N. Engl. J. Med. 2011, 364, 514-523. [CrossRef]

92. Pavel, M.E.; Hainsworth, J.D.; Baudin, E.; Peeters, M.; Hörsch, D.; Winkler, R.E.; Klimovsky, J.; Lebwohl, D.; Jehl, V.; Wolin, E.M.; et al. Everolimus plus Octreotide Long-Acting Repeatable for the treatment of advanced neuroendocrine tumours associated with carcinoid syndrome (RADIANT-2): A randomised, placebo-controlled, phase 3 study. Lancet 2011, 378, 2005-2012. [CrossRef]

93. Yao, J.C.; Fazio, N.; Singh, S.; Buzzoni, R.; Carnaghi, C.; Wolin, E.; Tomasek, J.; Raderer, M.; Lahner, H.; Voi, M.; et al. Everolimus for the treatment of advanced, non-functional neuroendocrine tumours of the lung or gastrointestinal tract (RADIANT-4): A randomised, placebo-controlled, phase 3 study. Lancet 2016, 387, 968-977. [CrossRef]

94. Pellat, A.; Dreyer, C.; Couffignal, C.; Walter, T.; Lombard-Bohas, C.; Niccoli, P.; Seitz, J.F.; Hentic, O.; André, T.; Coriat, R.; et al. Clinical and biomarker evaluations of Sunitinib in patients with grade 3 digestive neuroendocrine neoplasms. Neuroendocrinology 2018, 107, 24-31. [CrossRef]

95. Panzuto, F.; Rinzivillo, M.; Spada, F.; Antonuzzo, L.; Ibrahim, T.; Campana, D.; Fazio, N.; Delle Fave, G. Everolimus in pancreatic neuroendocrine carcinomas G3. Pancreas 2017, 46, 302-305. [CrossRef] [PubMed]

96. Xu, J.; Shen, L.; Zhou, Z.; Li, J.; Bai, C.; Chi, Y.; Li, Z.; Xu, N.; Li, E.; Liu, T.; et al. Surufatinib in advanced extrapancreatic neuroendocrine tumours (SANET-Ep): A randomised, double-blind, placebo-controlled, phase 3 study. Lancet Oncol. 2020, 21, 1500-1512. [CrossRef]

97. Moertel, C.G.; Lefkopoulo, M.; Lipsitz, S.; Hahn, R.G.; Klaassen, D. Streptozocin-doxorubicin, streptozocin-fluorouracil or chlorozotocin in the treatment of advanced islet-cell carcinoma. N. Engl. J. Med. 1992, 326, 519-523. [CrossRef] [PubMed]

98. Bajetta, E.; Rimassa, L.; Carnaghi, C.; Seregni, E.; Ferrari, L.; Di Bartolomeo, M.; Regalia, E.; Cassata, A.; Procopio, G.; Mariani, L. 5-Fluorouracil, dacarbazine, and epirubicin in the treatment of patients with neuroendocrine tumors. Cancer 1998, 83, 372-378. [CrossRef]

99. Strosberg, J.R.; Fine, R.L.; Choi, J.; Nasir, A.; Coppola, D.; Chen, D.-T.; Helm, J.; Kvols, L. First-line chemotherapy with capecitabine and temozolomide in Ppatients with metastatic pancreatic endocrine carcinomas. Cancer 2011, 117, 268-275. [CrossRef]

100. Kunz, P.L.; Catalano, P.J.; Nimeiri, H.; Fisher, G.A.; Longacre, T.A.; Suarez, C.J.; Yao, J.C.; Kulke, M.H.; Hendifar, A.E.; Shanks, J.C.; et al. A randomized study of temozolomide or temozolomide and capecitabine in patients with advanced pancreatic neuroendocrine tumors: A trial of the ECOG-ACRIN cancer research group (E2211). J. Clin. Oncol. 2018, 36, 4004. [CrossRef]

101. Ducreux, M.; Dahan, L.; Smith, D.; O’Toole, D.; Lepère, C.; Dromain, C.; Vilgrain, V.; Baudin, E.; Lombard-Bohas, C.; Scoazec, J.-Y.; et al. Bevacizumab combined with 5-FU/streptozocin in patients with progressive metastatic well-differentiated pancreatic endocrine tumours (BETTER Trial)-a phase II non-randomised rrial. Eur. J. Cancer 2014, 50, 3098-3106. [CrossRef] [PubMed]

102. Brixi-Benmansour, H.; Jouve, J.-L.; Mitry, E.; Bonnetain, F.; Landi, B.; Hentic, O.; Bedenne, L.; Cadiot, G. Phase II study of first-line FOLFIRI for progressive metastatic well-differentiated pancreatic endocrine carcinoma. Dig. Liver Dis. 2011, 43, 912-916. [CrossRef] [PubMed]

103. Bajetta, E.; Catena, L.; Procopio, G.; De Dosso, S.; Bichisao, E.; Ferrari, L.; Martinetti, A.; Platania, M.; Verzoni, E.; Formisano, B.; et al. Are capecitabine and oxaliplatin (XELOX) suitable treatments for progressing low-grade and high-grade neuroendocrine tumours? Cancer Chemother. Pharmacol. 2007, 59, 637-642. [CrossRef] [PubMed]

104. Dussol, A.-S.; Joly, M.-O.; Vercherat, C.; Forestier, J.; Hervieu, V.; Scoazec, J.-Y.; Lombard-Bohas, C.; Walter, T. Gemcitabine and oxaliplatin or alkylating agents for neuroendocrine tumors: Comparison of efficacy and search for predictive factors guiding treatment choice. Cancer 2015, 121, 3428-3434. [CrossRef]

105. Altimari, A.F.; Badrinath, K.; Reisel, H.J.; Prinz, R.A. DTIC therapy in patients with malignant intra-abdominal neuroendocrine tumors. Surgery 1987, 102, 1009-1017.

106. Bajetta, E.; Ferrari, L.; Procopio, G.; Catena, L.; Ferrario, E.; Martinetti, A.; Di Bartolomeo, M.; Buzzoni, R.; Celio, L.; Vitali, M.; et al. Efficacy of a chemotherapy combination for the treatment of metastatic neuroendocrine tumours. Ann. Oncol. 2002, 13, 614-621. [CrossRef] 
107. Ekeblad, S.; Sundin, A.; Janson, E.T.; Welin, S.; Granberg, D.; Kindmark, H.; Dunder, K.; Kozlovacki, G.; Orlefors, H.; Sigurd, M.; et al. Temozolomide as monotherapy Is effective in treatment of advanced malignant neuroendocrine tumors. Clin. Cancer Res. 2007, 13, 2986-2991. [CrossRef]

108. Yang, Q.-C.; Wang, Y.-H.; Lin, Y.; Xue, L.; Chen, Y.-J.; Chen, M.-H.; Chen, J. Expression of O(6)-Methylguanine DNA Methyltransferase (MGMT) and its clinical significance in gastroenteropancreatic neuroendocrine neoplasm. Int. J. Clin. Exp. Pathol. 2014, 7, 4204-4212.

109. Cassier, P.A.; Walter, T.; Eymard, B.; Ardisson, P.; Perol, M.; Paillet, C.; Chayvialle, J.-A.; Scoazec, J.-Y.; Hervieu, V.; Bohas, C.L. Gemcitabine and oxaliplatin combination chemotherapy for metastatic well-differentiated neuroendocrine carcinomas: A single-center experience. Cancer 2009, 115, 3392-3399. [CrossRef]

110. Mitry, E.; Walter, T.; Baudin, E.; Kurtz, J.-E.; Ruszniewski, P.; Dominguez-Tinajero, S.; Bengrine-Lefevre, L.; Cadiot, G.; Dromain, C.; Farace, F.; et al. Bevacizumab plus capecitabine in patients with progressive advanced well-differentiated neuroendocrine tumors of the gastro-intestinal (GI-NETs) tract (BETTER Trial)-a phase II non-randomised trial. Eur. J. Cancer 2014, 50, 3107-3115. [CrossRef]

111. Mitry, E.; Baudin, E.; Ducreux, M.; Sabourin, J.C.; Rufie, P.; Aparicio, T.; Aparicio, T.; Lasser, P.; Elias, D.; Duvillard, P.; et al. Treatment of poorly differentiated neuroendocrine tumours with etoposide and cisplatin. Br. J. Cancer 1999, 81, 1351-1355. [CrossRef]

112. Moertel, C.G.; Kvols, L.K.; O'Connell, M.J.; Rubin, J. Treatment of neuroendocrine carcinomas with combined etoposide and cisplatin. Evidence of major therapeutic activity in the anaplastic variants of these neoplasms. Cancer 1991, 68, 227-232. [CrossRef]

113. Nakano, K.; Takahashi, S.; Yuasa, T.; Nishimura, N.; Mishima, Y.; Sakajiri, S.; Yokoyama, M.; Tsuyama, N.; Ishikawa, Y.; Hatake, K. Feasibility and efficacy of combined cisplatin and irinotecan chemotherapy for poorly differentiated neuroendocrine carcinomas. Jpn. J. Clin. Oncol. 2012, 42, 697-703. [CrossRef]

114. Hentic, O.; Hammel, P.; Couvelard, A.; Rebours, V.; Zappa, M.; Palazzo, M.; Maire, F.; Goujon, G.; Gillet, A.; Levy, P.; et al. FOLFIRI regimen: An effective second-line chemotherapy after failure of etoposide-platinum combination in patients with neuroendocrine carcinomas grade 3. Endocr. Relat. Cancer 2012, 19, 751-757. [CrossRef]

115. Hadoux, J.; Malka, D.; Planchard, D.; Scoazec, J.Y.; Caramella, C.; Guigay, J.; Boige, V.; Leboulleux, S.; Burtin, P.; Berdelou, A.; et al Post-first-line FOLFOX chemotherapy for grade 3 neuroendocrine carcinoma. Endocr. Relat. Cancer 2015, 22, 289-298. [CrossRef]

116. Welin, S.; Sorbye, H.; Sebjornsen, S.; Knappskog, S.; Busch, C.; Oberg, K. Clinical effect of temozolomide-based chemotherapy in poorly differentiated endocrine carcinoma after progression on first-line chemotherapy. Cancer 2011, 117, 4617-4622. [CrossRef]

117. Sahu, A.; Jefford, M.; Lai-Kwon, J.; Thai, A.; Hicks, R.J.; Michael, M. CAPTEM in metastatic well-differentiated intermediate to high grade neuroendocrine tumors: A single centre experience. J. Oncol. 2019, 2019, 9032753. [CrossRef]

118. Lu, Y.; Zhao, Z.; Wang, J.; Lv, W.; Lu, L.; Fu, W.; Li, W. Safety and efficacy of combining capecitabine and temozolomide (CAPTEM) to treat advanced neuroendocrine neoplasms: A meta-analysis. Medicine 2018, 97, e12784. [CrossRef]

119. Thomas, K.; Voros, B.A.; Meadows-Taylor, M.; Smeltzer, M.P.; Griffin, R.; Boudreaux, J.P.; Thiagarajan, R.; Woltering, E.A.; Ramirez, R.A. Outcomes of capecitabine and temozolomide (CAPTEM) in advanced neuroendocrine neoplasms (NENs). Cancers 2020, 12, 206. [CrossRef]

120. De Mestier, L.; Walter, T.; Evrard, C.; de Boissieu, P.; Hentic, O.; Cros, J.; Tougeron, D.; Lombard-Bohas, C.; Rebours, V.; Hammel, P.; et al. Temozolomide alone or combined with capecitabine for the treatment of advanced pancreatic neuroendocrine tumor. Neuroendocrinology 2020, 110, 83-91. [CrossRef]

121. Ostwal, V.; Basu, S.; Bhargava, P.; Shah, M.; Parghane, R.V.; Srinivas, S.; Chaudhari, V.; Bhandare, M.S.; Shrikhande, S.V.; Ramaswamy, A. Capecitabine-temozolomide (CAPTEM) in advanced grade 2 and grade 3 neuroendocrine neoplasms (NENs)benefits of chemotherapy in NENs with significant 18FDG uptake. Neuroendocrinology 2020. [CrossRef] [PubMed]

122. Strosberg, J.; El-Haddad, G.; Wolin, E.; Hendifar, A.; Yao, J.; Chasen, B.; Mittra, E.; Kunz, P.L.; Kulke, M.H.; Jacene, H.; et al. Phase 3 trial of 177Lu-Dotatate for midgut neuroendocrine tumors. N. Engl. J. Med. 2017, 376, 125-135. [CrossRef] [PubMed]

123. Brabander, T.; van der Zwan, W.A.; Teunissen, J.J.M.; Kam, B.L.R.; Feelders, R.A.; de Herder, W.W.; van Eijck, C.H.J.; Franssen, G.J.H.; Krenning, E.P.; Kwekkeboom, D.J. Long-term efficacy, survival, and safety of [177Lu-DOTA0,Tyr3]Octreotate in patients with gastroenteropancreatic and bronchial neuroendocrine tumors. Clin. Cancer Res. 2017, 23, 4617-4624. [CrossRef]

124. Reidy-Lagunes, D.; Pandit-Taskar, N.; O’Donoghue, J.A.; Krebs, S.; Staton, K.D.; Lyashchenko, S.K.; Lewis, J.S.; Raj, N.; Gönen, M.; Lohrmann, C.; et al. Phase I trial of well-differentiated neuroendocrine tumors (NETs) with radiolabeled somatostatin antagonist 177Lu-Satoreotide tetraxetan. Clin. Cancer Res. 2019, 25, 6939-6947. [CrossRef] [PubMed]

125. Sorbye, H.; Kong, G.; Grozinsky-Glasberg, S. PRRT in High-grade gastroenteropancreatic neuroendocrine neoplasms (WHO G3). Endocr. Relat. Cancer 2020, 27, R67-R77. [CrossRef]

126. Carlsen, E.A.; Fazio, N.; Granberg, D.; Grozinsky-Glasberg, S.; Ahmadzadehfar, H.; Grana, C.M.; Zandee, W.T.; Cwikla, J.; Walter, M.A.; Oturai, P.S.; et al. Peptide receptor radionuclide therapy in gastroenteropancreatic NEN G3: A multicenter cohort study. Endocr. Relat. Cancer 2019, 26, 227-239. [CrossRef]

127. Pavel, M.; Öberg, K.; Falconi, M.; Krenning, E.P.; Sundin, A.; Perren, A.; Berruti, A.; ESMO Guidelines Committee. Gastroenteropancreatic neuroendocrine neoplasms: ESMO clinical practice guidelines for diagnosis, treatment and follow-up. Ann. Oncol. 2020, 31, 844-860. [CrossRef] [PubMed] 
128. Basu, S.; Adnan, A. Well-differentiated grade 3 neuroendocrine tumours and poorly differentiated grade 3 neuroendocrine carcinomas: Will dual tracer PET-Computed Tomography (68Ga-DOTATATE and FDG) play a pivotal role in differentiation and guiding management strategies? Nucl. Med. Commun. 2019, 40, 1086-1087. [CrossRef]

129. Strosberg, J.; Mizuno, N.; Doi, T.; Grande, E.; Delord, J.-P.; Shapira-Frommer, R.; Bergsland, E.; Shah, M.; Fakih, M.; Takahashi, S.; et al. Efficacy and safety of pembrolizumab in previously treated advanced neuroendocrine tumors: Results from the phase II KEYNOTE-158 study. Clin. Cancer Res. 2020, 26, 2124-2130. [CrossRef]

130. Weber, M.M.; Fottner, C. Immune checkpoint Inhibitors in the treatment of patients with neuroendocrine Neoplasia. Oncol. Res. Treat. 2018, 41, 306-312. [CrossRef]

131. Nghiem, P.T.; Bhatia, S.; Lipson, E.J.; Kudchadkar, R.R.; Miller, N.J.; Annamalai, L.; Berry, S.; Chartash, E.K.; Daud, A.; Fling, S.P.; et al. PD-1 blockade with pembrolizumab in advanced Merkel-cell carcinoma. N. Engl. J. Med. 2016, 374, 2542-2552. [CrossRef]

132. Kaufman, H.L.; Russell, J.; Hamid, O.; Bhatia, S.; Terheyden, P.; D’Angelo, S.P.; Shih, K.C.; Lebbé, C.; Linette, G.P.; Milella, M.; et al. Avelumab in patients with chemotherapy-refractory metastatic Merkel cell carcinoma: A multicentre, single-group, open-label, phase 2 trial. Lancet Oncol. 2016, 17, 1374-1385. [CrossRef]

133. Vijayvergia, N.; Dasari, A.; Deng, M.; Litwin, S.; Al-Toubah, T.; Alpaugh, R.K.; Dotan, E.; Hall, M.J.; Ross, N.M.; Runyen, M.M.; et al. Pembrolizumab monotherapy in patients with previously treated metastatic high-grade neuroendocrine neoplasms: Joint analysis of two prospective, non-randomised rrials. Br. J. Cancer 2020, 122, 1309-1314. [CrossRef] 